\title{
Quality Assurance Project Plan for the Gas Generation Testing Program at the INEL
}

Published October 1994

Science Application International Corporation

Waste Management Technology Division

545 Shoup Avenue

Idaho Falls, ID 83402-3575

\footnotetext{
Prepared for the
}

U.S. Department of Energy

Assistant Secretery for Environmental Management

Under DOE Idaho Operations Office

Contract DE-AC07-941D13223

DISTRIBUTION OF THIS DOCUMENT. IS UNLLMKTED 


\section{DISCLAIMER}

This report was prepared as an account of work sponsored by an agency of the United States Government. Neither the United States Government nor any agency thereof, nor any of their employees, makes any warranty, express or implied, or assumes any legal liability or responsibility for the accuracy, completeness, or usefulness of any information, apparatus, product, or process disclosed, or represents that its use would not infringe privately owned rights. Reference herein to any specific commercial product, process, or service by trade name, trademark, manufacturer, or otherwise does not necessarily constitute or imply its endorsement, recommendation, or favoring by the United States Government or any agency thereof. The views and opinions of authors expressed herein do not necessarily state or reflect those of the United States Government or any agency thereof. 


\section{DISCLAIMER}

Portions of this document may be illegible in electronic image products. Images are produced from the best available original document. 


\section{Quality Assurance Project Plan for the Gas Generation Testing Program at the INEL}

Approved by

DOE-ID Ficld Office

QlB for GASchroder, Rwim QE

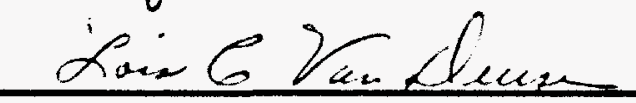

L. C. VanDeusen

Radioactive Waste Management Complex Manager

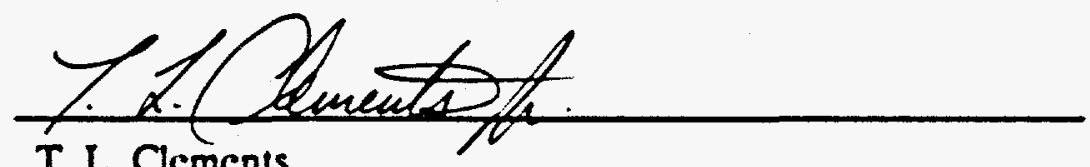

T. L. Clements

TRU Waste Programs Unit Manager

Reviewed by

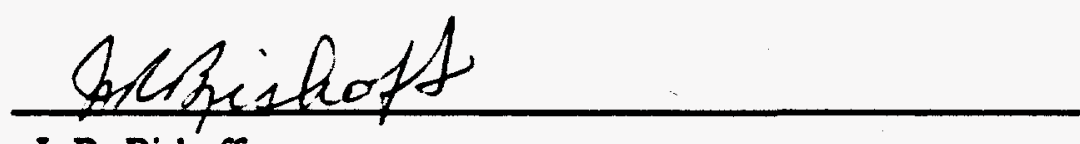

J. R. Bishoff

RWMC Operations Manager

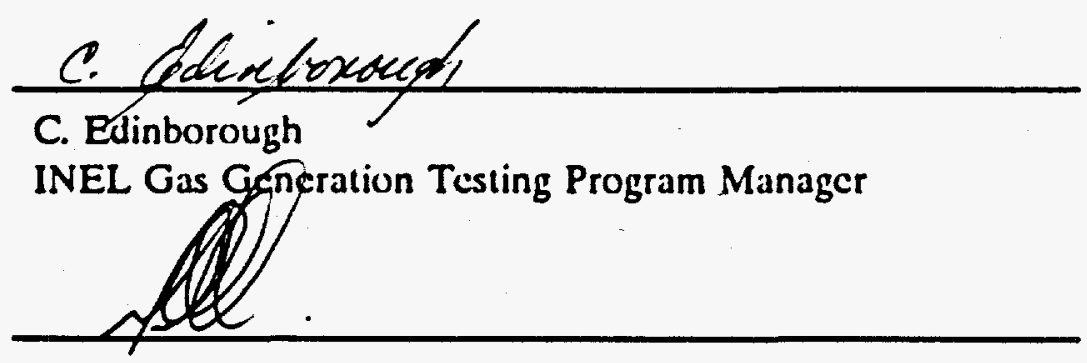

G. A. Schroder

RWMC Quality Enginecr

\section{Date}

$17 m+Y 1994$

$5 / 16 / 94$

Date

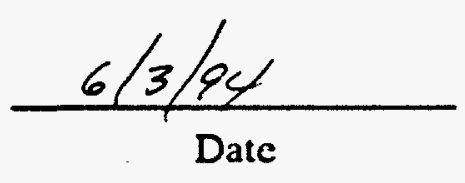

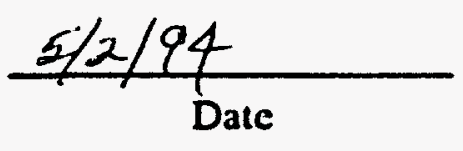

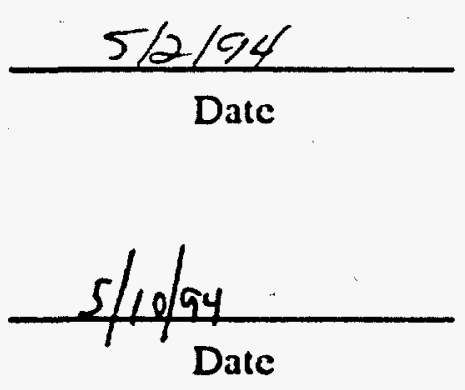




\begin{abstract}
This Quality Assurance Project Plan (QAPjP) specifies the data quality needed in order for the Idaho National Engineering Laboratory (INEL) to meet the objectives of the Transuranic Package Transporter-II (TRUPACT-II) Gas Generation Testing Program and the Quality Assurance Program Plan for the TRUPACT.II Gas Generation Test Program. This QAPjP is based on the guidance in the U.S. Environmental Protection Agency (EPA) document, Guidelines and Specifications for Preparing Quality Assurance Project Plans, QAMS-005/80 (EPA, 1983b) and meets the requirements provided in U.S. Department of Energy (DOE) Order 5700.6C, "Quality Assurance."

The data quality objectives (DQOs) for the Program are to evaluate compliance with the limits on total gas generation rates, establish the concentrations of hydrogen and methane in the total gas flow, determine the headspace concentration of VOCs in each drum prior to the start of the test, and obtain estimates of the concentrations of several compounds for mass balance purposes.
\end{abstract}

Criteria for the selection of waste containers at the INEL and the parameters that must be characterized prior to and during the tests are described. Collection of gaseous samples from 55-gallon drums of contacthandled transuranic waste for the gas generation testing is discussed. Analytical methods and calibrations are summarized. Administrative quality control measures described in this QAPjP include the generation, review, and approval of project documentation; control and retention of records; measures to ensure that personnel, subcontractors or vendors, and equipment meet the specifications necessary to achieve the required data quality for the project. 



\section{CONTENTS}

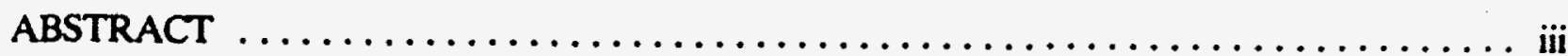

ACRONYMS $\ldots \ldots \ldots \ldots \ldots \ldots \ldots \ldots \ldots \ldots \ldots \ldots \ldots \ldots \ldots \ldots \ldots \ldots \ldots \ldots \ldots \ldots$

1. PROJECT DESCRIPTION $\ldots \ldots \ldots \ldots \ldots \ldots \ldots \ldots \ldots \ldots \ldots \ldots \ldots \ldots \ldots$, 1

1.1 Program Overview $\ldots \ldots \ldots \ldots \ldots \ldots \ldots \ldots \ldots \ldots \ldots \ldots \ldots \ldots \ldots, 1$

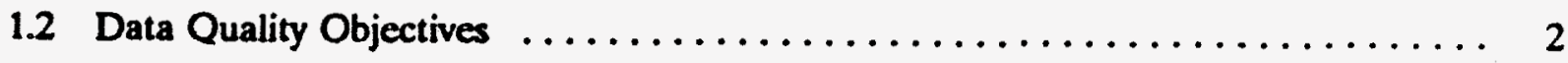

1.3 Document Review, Approval, and Control $\ldots \ldots \ldots \ldots \ldots \ldots \ldots \ldots \ldots$

1.3.1 Review and Approval of Documents ...................... 4

1.3.2 Document Control $\ldots \ldots \ldots \ldots \ldots \ldots \ldots \ldots \ldots \ldots \ldots \ldots \ldots, 4$

1.3.3 Change Control $\ldots \ldots \ldots \ldots \ldots \ldots \ldots \ldots \ldots \ldots \ldots \ldots \ldots, 4$

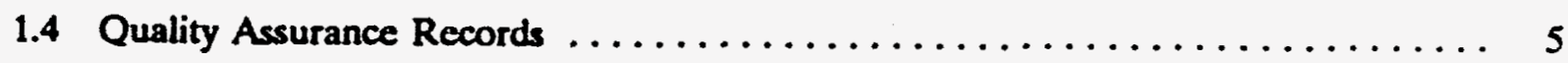

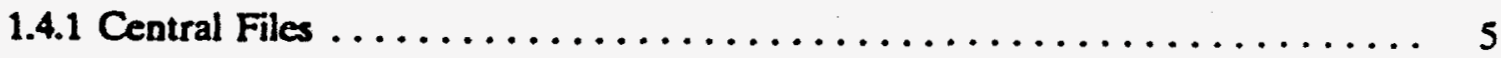

1.4 .2 Record Retention $\ldots \ldots \ldots \ldots \ldots \ldots \ldots \ldots \ldots \ldots \ldots \ldots \ldots \ldots, 5$

1.4 .3 Laboratory Files $\ldots \ldots \ldots \ldots \ldots \ldots \ldots \ldots \ldots \ldots \ldots \ldots \ldots, 6$

1.5 Procurement Document Control/Control of Subcontractors $\ldots \ldots \ldots \ldots \ldots$

1.5.1 Procurement Document Control ...................... 6

1.5.2 Contm' of Subcontractors .......................... 6

1.5.3 Control of Purchased Items and Services .................. 7

1.5.4 Identification and Control of Items $\ldots \ldots \ldots \ldots \ldots \ldots \ldots \ldots \ldots, 7$

1.5.5 Control of Processes ............................ 7

1.6 Personnel Qualification and Training $\ldots \ldots \ldots \ldots \ldots \ldots \ldots \ldots \ldots \ldots, 7$

1.7 Analytical Laboratory (Environmental Chemistry Laboratory) $\ldots \ldots \ldots \ldots \ldots 8$

2. PROJECT ORGANIZATION AND RESPONSIBILITIES $\ldots \ldots \ldots \ldots \ldots \ldots \ldots$

21 INEL Gas Generation Testing Program Manager $\ldots \ldots \ldots \ldots \ldots \ldots \ldots$

2.2 Quality Assurance Officer $\ldots \ldots \ldots \ldots \ldots \ldots \ldots \ldots \ldots \ldots \ldots \ldots$

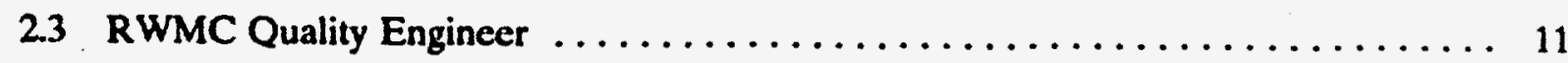

24 Data Validation Officer $\ldots \ldots \ldots \ldots \ldots \ldots \ldots \ldots \ldots \ldots \ldots \ldots \ldots \ldots \ldots \ldots$ 
2.6 Operations Personncl $\ldots \ldots \ldots \ldots \ldots \ldots \ldots \ldots \ldots \ldots \ldots \ldots \ldots \ldots \ldots \ldots$

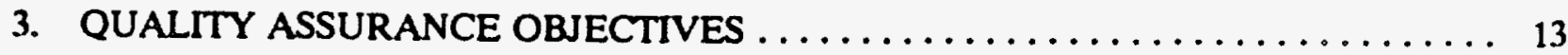

3.1 Gas Sampling $\ldots \ldots \ldots \ldots \ldots \ldots \ldots \ldots \ldots \ldots \ldots \ldots \ldots \ldots \ldots \ldots \ldots$

3.1 .1 Precision $\ldots \ldots \ldots \ldots \ldots \ldots \ldots \ldots \ldots \ldots \ldots \ldots \ldots \ldots \ldots \ldots \ldots \ldots$

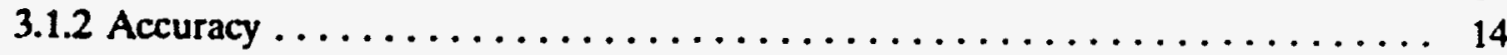

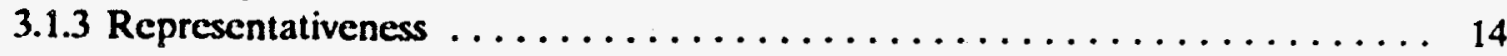

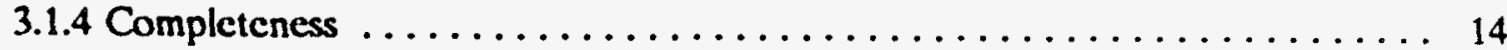

3.1.5 Comparability .......................... 14

3.2 Gas Flow Measurements . . . . . . . . . . . . . . . . . . . . 14

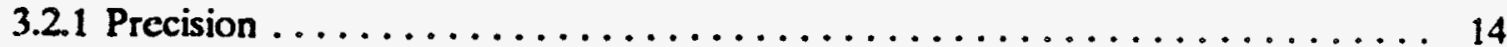

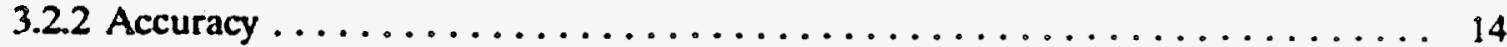

3.2 .3 Representativeness $\ldots \ldots \ldots \ldots \ldots \ldots \ldots \ldots \ldots \ldots \ldots \ldots \ldots \ldots \ldots \ldots$

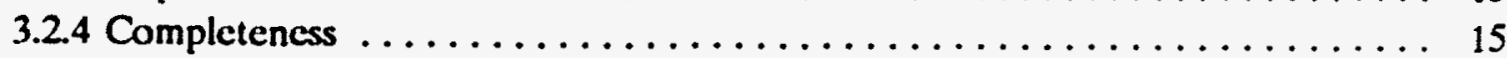

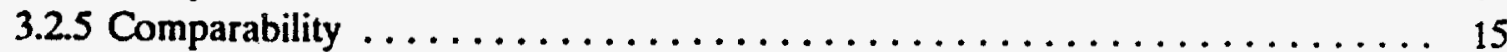

3.3 Hydrogen/Methane Gas Analysis $\ldots \ldots \ldots \ldots \ldots \ldots \ldots \ldots \ldots \ldots \ldots \ldots \ldots \ldots \ldots$

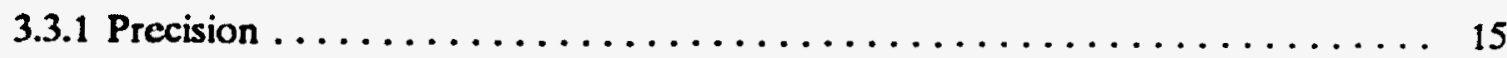

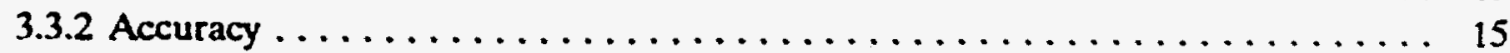

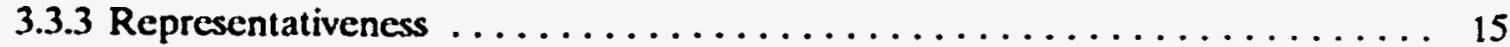

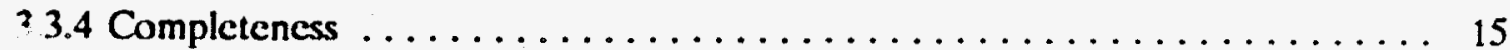

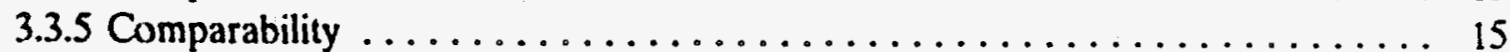

3.4 Volatile Organic Compound Analyses $\ldots \ldots \ldots \ldots \ldots \ldots \ldots \ldots \ldots \ldots \ldots \ldots \ldots \ldots$

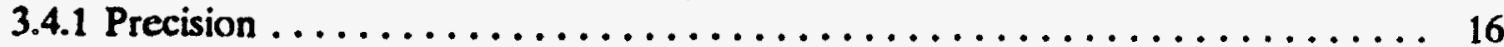

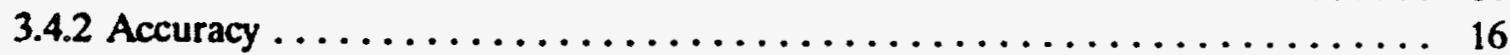

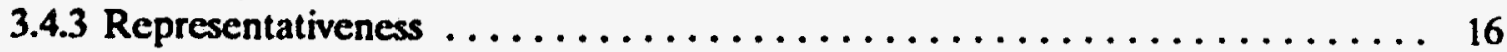

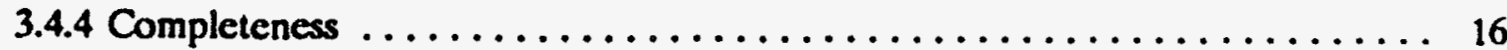

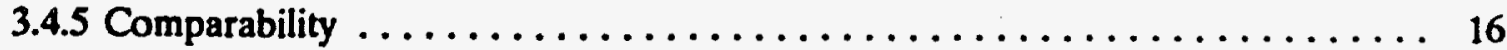

3.5 Mass Balance Parameters $\ldots \ldots \ldots \ldots \ldots \ldots \ldots \ldots \ldots \ldots \ldots \ldots \ldots \ldots$

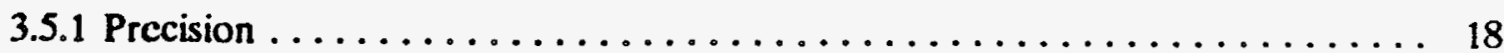

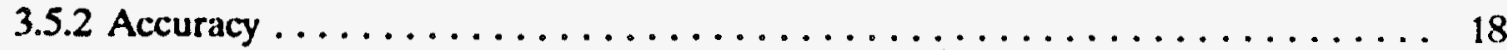

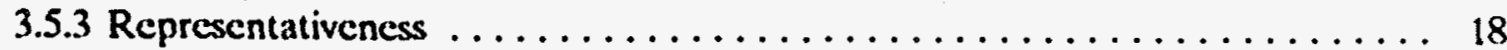

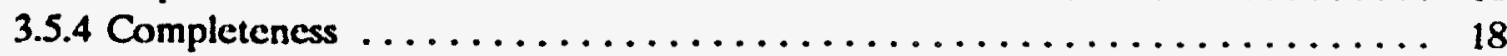

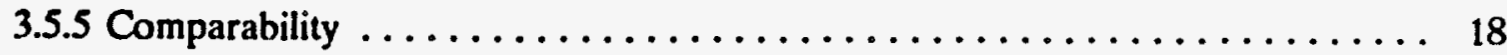




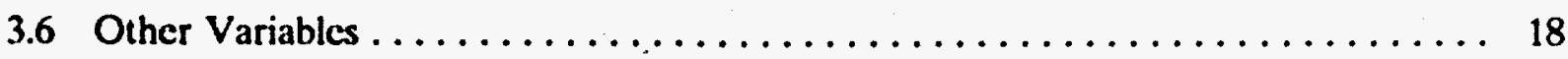

3.6.1 Temperature ................................... 18

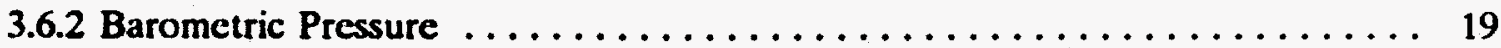

4. WASTE CONTAINER SELECTION AND PRETEST CHARACTERIZATION $\ldots \ldots 20$

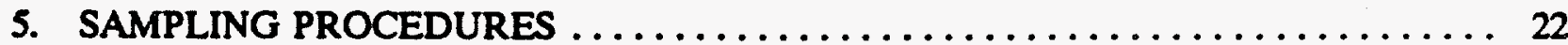

5.1 Sampling Protocol $\ldots \ldots \ldots \ldots \ldots \ldots \ldots \ldots \ldots \ldots \ldots \ldots \ldots \ldots \ldots \ldots \ldots \ldots \ldots, 22$

5.2 Sampling Manifold Cleaning $\ldots \ldots \ldots \ldots \ldots \ldots \ldots \ldots \ldots \ldots \ldots \ldots \ldots \ldots \ldots \ldots, 22$

5.3 Container Cleaning $\ldots \ldots \ldots \ldots \ldots \ldots \ldots \ldots \ldots \ldots \ldots \ldots \ldots \ldots \ldots \ldots \ldots \ldots \ldots \ldots \ldots, 22$

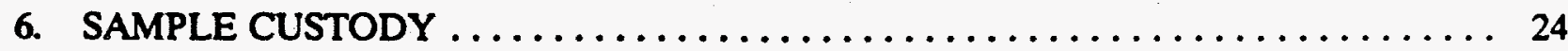

7. CALIBRATION PROCEDURES AND FREQUENCY $\ldots \ldots \ldots \ldots \ldots \ldots \ldots$

7.1 Sampling Manifold $\ldots \ldots \ldots \ldots \ldots \ldots \ldots \ldots \ldots \ldots \ldots \ldots \ldots \ldots \ldots \ldots \ldots \ldots \ldots, 28$

7.2 Gas Flow Measurement $\ldots \ldots \ldots \ldots \ldots \ldots \ldots \ldots \ldots \ldots \ldots \ldots \ldots \ldots \ldots \ldots \ldots \ldots \ldots, 28$

7.3 Hydrogen, Methane, and Volatile Organic Compound Analyses .......... 28

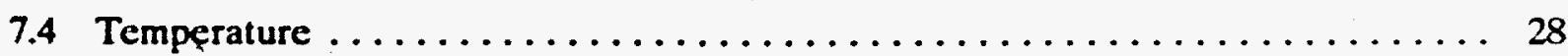

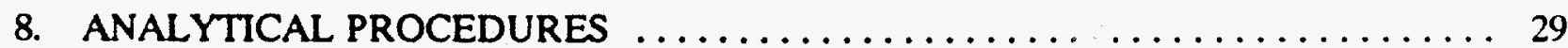

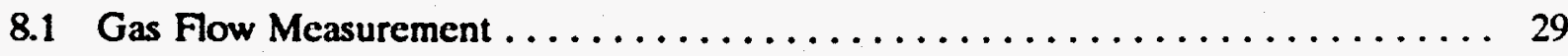

8.2 Hydrogen, Methane, and Volatile Organic Compound Analyses ........... 29

8.3 Temperature $\ldots \ldots \ldots \ldots \ldots \ldots \ldots \ldots \ldots \ldots \ldots \ldots \ldots \ldots \ldots .29$

9. DATA REDUCTION, VALIDATION, AND REPORTING $\ldots \ldots \ldots \ldots \ldots \ldots \ldots .30$

9.1 Gas Fow Measurement $\ldots \ldots \ldots \ldots \ldots \ldots \ldots \ldots \ldots \ldots \ldots \ldots \ldots \ldots \ldots$

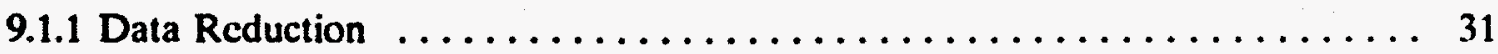

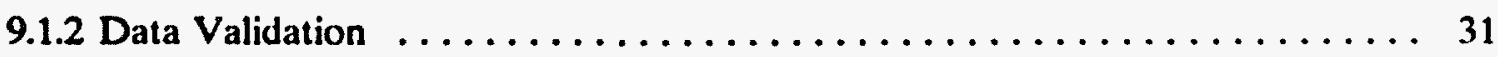

9.1.3 Data Reporting $\ldots \ldots \ldots \ldots \ldots \ldots \ldots \ldots \ldots \ldots \ldots \ldots \ldots \ldots \ldots \ldots \ldots \ldots, 31$

9.2 Hydrogen and Methane Gas Analyses $\ldots \ldots \ldots \ldots \ldots \ldots \ldots \ldots \ldots \ldots \ldots \ldots \ldots$

9.2.1 Data Reduction $\ldots \ldots \ldots \ldots \ldots \ldots \ldots \ldots \ldots \ldots \ldots \ldots \ldots \ldots \ldots$ 


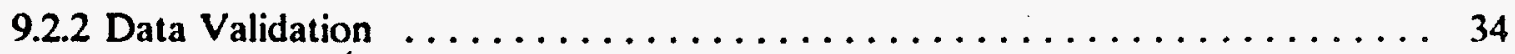

9.2.3 Data Reporting ........................... 34

9.3 Volatile Organic Compound Analyses $\ldots \ldots \ldots \ldots \ldots \ldots \ldots \ldots \ldots \ldots \ldots \ldots$

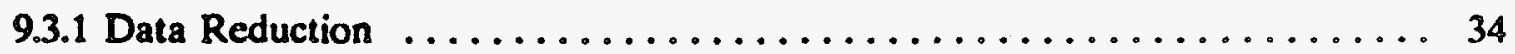

9.3.2 Data Validation . . . . . . . . . . . . . . . . . . . . . . . . 34

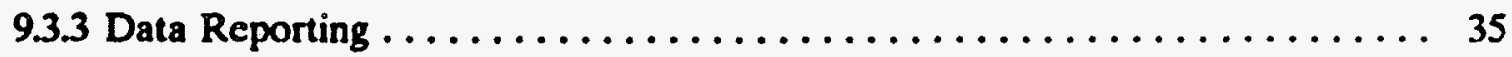

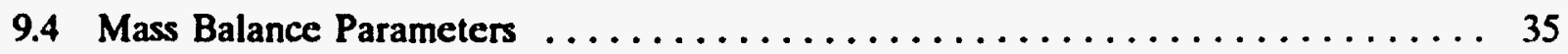

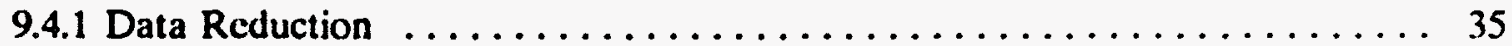

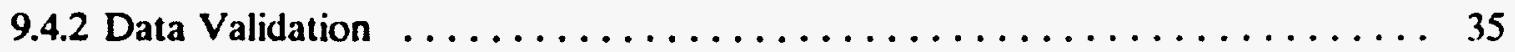

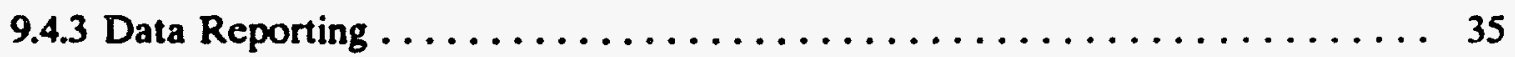

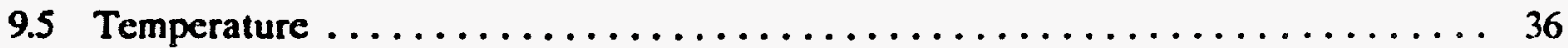

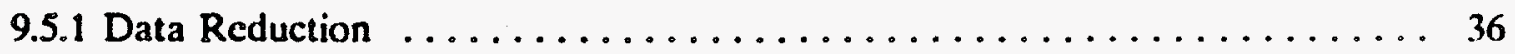

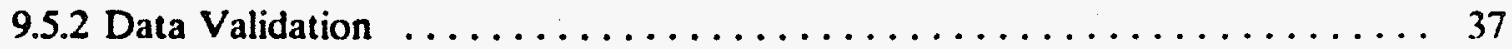

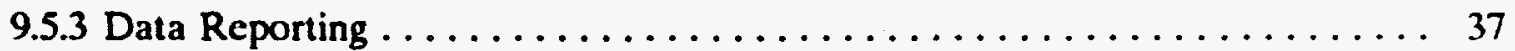

10. INTERNAL QUALITY CONTROL CHECKS AND FREQUENCY $\ldots \ldots \ldots \ldots \ldots 38$

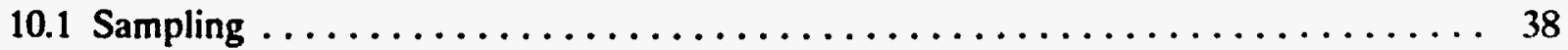

10.2 Hydrogen. Methane, and Volatile Organic Compound Aralyses .......... 38

11. PERFORMANCE AND SYSTEMS AUDITS $\ldots \ldots \ldots \ldots \ldots \ldots \ldots \ldots \ldots \ldots$

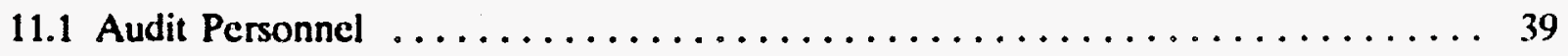

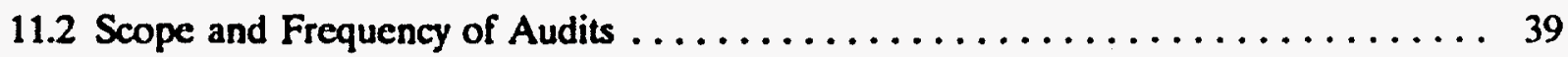

12. PREVENTIVE MAINTENANCE $\ldots \ldots \ldots \ldots \ldots \ldots \ldots \ldots \ldots \ldots \ldots \ldots \ldots \ldots$

13. SPECIFIC AND ROUTINE PROCEDURES TO ASSESS DATA QUALITY $\ldots \ldots \ldots 41$

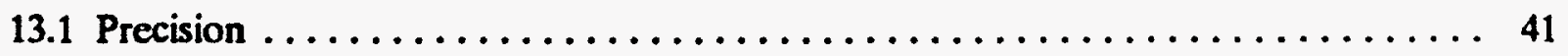

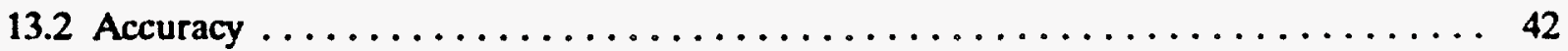

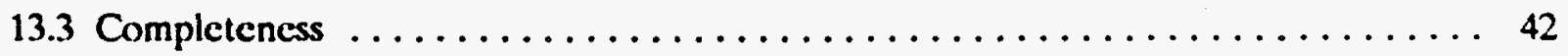

13.4 Method Detection Limit $\ldots \ldots \ldots \ldots \ldots \ldots \ldots \ldots \ldots \ldots \ldots \ldots \ldots, 43$

14. CORRECTIVE ACTION $\ldots \ldots \ldots \ldots \ldots \ldots \ldots \ldots \ldots \ldots \ldots \ldots \ldots \ldots \ldots \ldots \ldots \ldots \ldots$ 
14.1 Nonconformance

14.2 Variances

15. QUALITY ASSURANCE REPORTS TO MANAGEMENT .

16. REFERENCES

\section{FIGURES}

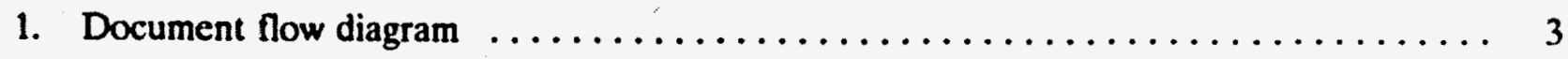

2. INEL Gas Gencration Testing Project functional organization diagram $\ldots \ldots \ldots \ldots \ldots$

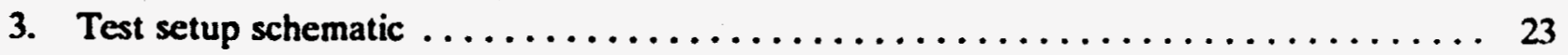

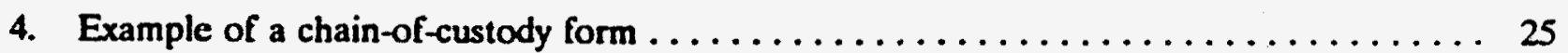

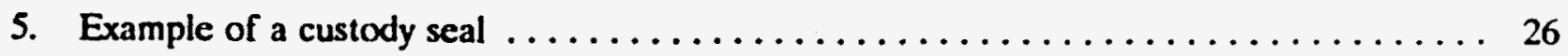

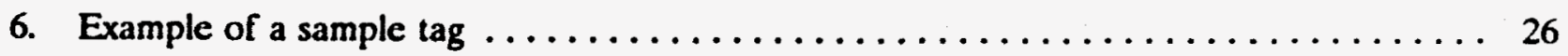

7. Example of a reporting form for gas flow measurements $\ldots \ldots \ldots \ldots \ldots \ldots$

8. Example of a reporting form for hydrogen/methane analyses $\ldots \ldots \ldots \ldots \ldots \ldots$

9. Example of a reporting form for mass balance parameters $\ldots \ldots \ldots \ldots \ldots \ldots \ldots$

10. Example of a reporting form for tempcrature measurements $\ldots \ldots \ldots \ldots \ldots \ldots \ldots$

11. Example of a nonconformance report $\ldots \ldots \ldots \ldots \ldots \ldots \ldots \ldots \ldots \ldots \ldots$

12. Example of a variance form $\ldots \ldots \ldots \ldots \ldots \ldots \ldots \ldots \ldots \ldots \ldots \ldots \ldots \ldots \ldots$

\section{TABLES}

1. Document review matrix for the INEL Gas Generation Testing Program QAPjP . . . . . 4

2. Quality assurance objectives for gas flow rate measurements $\ldots \ldots \ldots \ldots \ldots \ldots$

3. Quality assurance objectives for hydrogen/methane concentration measurements . . . . 16

4. Quality assurance objectives for VOCs in headspace gases $\ldots \ldots \ldots \ldots \ldots \ldots$

5. Quality assurance objectives for mass balance parameter measurements $\ldots \ldots \ldots \ldots \ldots 18$ 
6. Quality assurance objectives for temperature measurements $\ldots \ldots \ldots \ldots \ldots$

7. Decay heat criteria for drum selection $\ldots \ldots \ldots \ldots \ldots \ldots \ldots \ldots \ldots \ldots \ldots \ldots \ldots$

8. Sample containers and holding times for VOC sample collection . . . . . . . . . 22

9. Maximum total gas release rates for test categories $\ldots \ldots \ldots \ldots \ldots \ldots \ldots$ 


\section{ACRONYMS}

ASME

ASTM

CAO

CH

COC

DOE

DOE-HQ

DOE-ID

DOP

DOT

DQO

ECL

EPA

HP

INEL

IWG

MDL

MS

NCR

NIST

NQA-1

NRC

OsMM
American Society of Mechanical Engineers

American Society of Testing and Materials

Carlsbad Area Office

contact-handled

chain of custody

Department of Energy

Department of Energy - Headquarters

Department of Energy - Idaho Operations Office

detailed operating procedure

Department of Transportation

data quality objective

Environmental Chemistry Laboratory

Environmental Protection Agency

health physicist

Idaho National Engineering Laboratory

integrated working group

method detection limit

mass spectrometry

nonconformance report

National Institute of Standards and Technology

Nuclear Quality Assurance - 1

Nuclear Regulatory Commission

Operating and Maintenance Manual 


\begin{tabular}{ll} 
PD & project directive \\
PM & preventive maintenance \\
QA & quality assurance \\
QAMS & quality assurance management staff \\
QAO & quality assurance objective \\
QAPjP & Quality Assurance Project Plan \\
QAPP & Quality Assurance Program Plan \\
QC & quality control \\
RA & radioassay \\
RPD & relative percent deviation \\
RSD & relative standard deviation \\
RTR & real-time radiography \\
RWMC & Radioactive Waste Management Complex \\
SOP & standard operating procedure \\
SPO & Wite Project Office \\
SWEPP & Stored Waste Examination Pilot Plant \\
SWR & site work release \\
TRAMPAC & TRUPACT-II Authorized Methods for Payload Control \\
TRUCON & TRUPACT-II Content Codes \\
WRUPACT-II & Transuranic Package Transporter - II \\
VOC & volatile organic compound \\
WAC & waste \\
WIPPtance criteria \\
\hline
\end{tabular}




\section{Quality Assurance Project Plan for the Gas Generation Testing Program at the INEL}

\section{PROJECT DESCRIPTION}

\subsection{Program Overview}

The Transuranic Package Transporter-II (TRUPACT-II) Gas Generation Testing Program at the Idaho National Engineering Laboratory (INEL) consists of performing controlled tests with actual containers of INEL contact-handled (CH) transuranic (TRU) waste to collect data and quantify the gas generation properties of the waste under simulated transportation thermal conditions. The TRUPACT-II package is a Type B package designed for transporting CH-TRU waste containers to the Waste Isolation Pilot Plant (WIPP) for emplacement and disposal. One of the transportation parameters of concern for the TRUPACT-II package is the potential generation of hydrogen and methane from the radiolysis of waste materials or packaging. The concentration of hydrogen in the TRUPACT-II package during a minimum 60-day shipping period is limited to $5 \%$ (by volume). CH-TRU containers of waste that can be shipped without the need for testing comprise the analytical category and are qualified for shipment based on theoretical worst-case calculations. CH-TRU containers of waste that exceed the decay heat limits set for the analytical category or that do not have established theoretical upper bounds for gas generation potential comprise the test category and are the wastes used in this project.

The Program has two primary objectives. The first, or short-term, objective is to facilitate shipment of waste containers in the test category by testing individual containers of waste and showing compliance with applicable hydrogen and total gas generation rate limits. This will support the waste form requirements and schedules of the WIPP Experimental-Waste Characterization Program. The second, or long-term, objective of the Program is to improve waste shipability (as defined in the TRUPACT-II Certificate of Compliance) for specific populations and to re-evaluate transportation requirements related to decay heat limits, so that a larger fraction of the waste can be transported under the analytical category.

The activities associated with this Program at the INEL will be conducted at the Radioactive Waste Management Complex (RWMC). The RWMC has served as a major interim storage site for defense-generated TRU waste. The INEL currently has approximately $65 \%$ of the total defense-generated TRU waste inventory placed in aboveground retrievable storage at the RWMC.

The Stored Waste Examination Pilot Plant (SWEPP) is located within the RWMC. This facility provides storage, retrieval, drum venting, nondestructive examination and assay capability, and loading of stored TRU waste into the TRUPACT-II shipping containers. Nondestructive examination and assay of stored CH-TRU waste has been performed since August 1985. At that time, the facility was approved by the WIPP Waste Acceptance Criteria Certification Committee to certify CH-TRU waste for disposal at the WIPP based on the WIPP Waste Acceptance Criteria (WAC). The SWEPP facility verifies that waste complies with WIPP WAC and 
TRUPACT-II Authorized Methods for Payload Control (TRAMPAC). All testing and sampling activities for this project will be conducted in the SWEPP.

This document is consistent with the Quality Assurance Program Plan for the TRUPACT-II Gas Generation Test Program, second draft.

\subsection{Data Quality Objectives}

The purpose of data quality objectives is to produce data of known and sufficient quality for the Program. The data quality objectives for this Program are as follows:

- Gas Flow Measurement-Establish the total gas flow as a function of time. This information will be used to evaluate compliance with the limit on the total gas generation rate for the waste container.

- Hydrogen/Methane Gas Sampling and Analyses-Establish the concentrations of hydrogen and methane in the total gas flow. This information will be used to assess compliance with the limitations on flammable gas concentrations during shipment.

- Volatile Organic Compound (NOC) Sampling and Analyses-Establish the headspace concentration of VOCs prior to the start of the test on each drum. This information will be used to ensure that shipped drums satisfy the limits on flammable VOCs.

- Mass Balance Parameters-Obtain estimates of the relative humidity and the concentrations of oxygen $\left(\mathrm{O}_{2}\right)$, nitrogen $\left(\mathrm{N}_{2}\right)$, carbon dioxide $\left(\mathrm{CO}_{2}\right)$, and argon (Ar) for mass balance purposes.

\subsection{Document Review, Approval, and Control}

Documents that specify quality requirements or prescribe activities affecting quality for this project include the national program's Quality Assurance Program Plan (QAPP), this QAPjP, the RWMC Quality Program Plan, and RWMC project directives (PDs), which shall be controlled to ensure that correct documents are used and referenced. These documents and their interrelationships are presented in the flow diagram in Figure 1. RWMC PD-RS-3.6, "Document Preparation and Control," establishes policy, assigns responsibility for the preparation of new documents, and provides control for revising existing documents.

Detailed operating procedures (DOPs) and standard operating procedures (SOPs) shall be used to detail activities requiring written instructions. RWMC PD-RS-1.13, "Use of DOPs and SOPs," establishes the practices for use of DOPs and SOPs. Specific RWMC responsibilities are defined in RWMC project directives (PDs) and in waste packaging criteria. The PDs are used to establish responsibilities and to implement specific operating and maintenance manuals, quality plans, engineering drawings and specifications, operating procedures, equipment specifications, manuals, reports, and logs. 


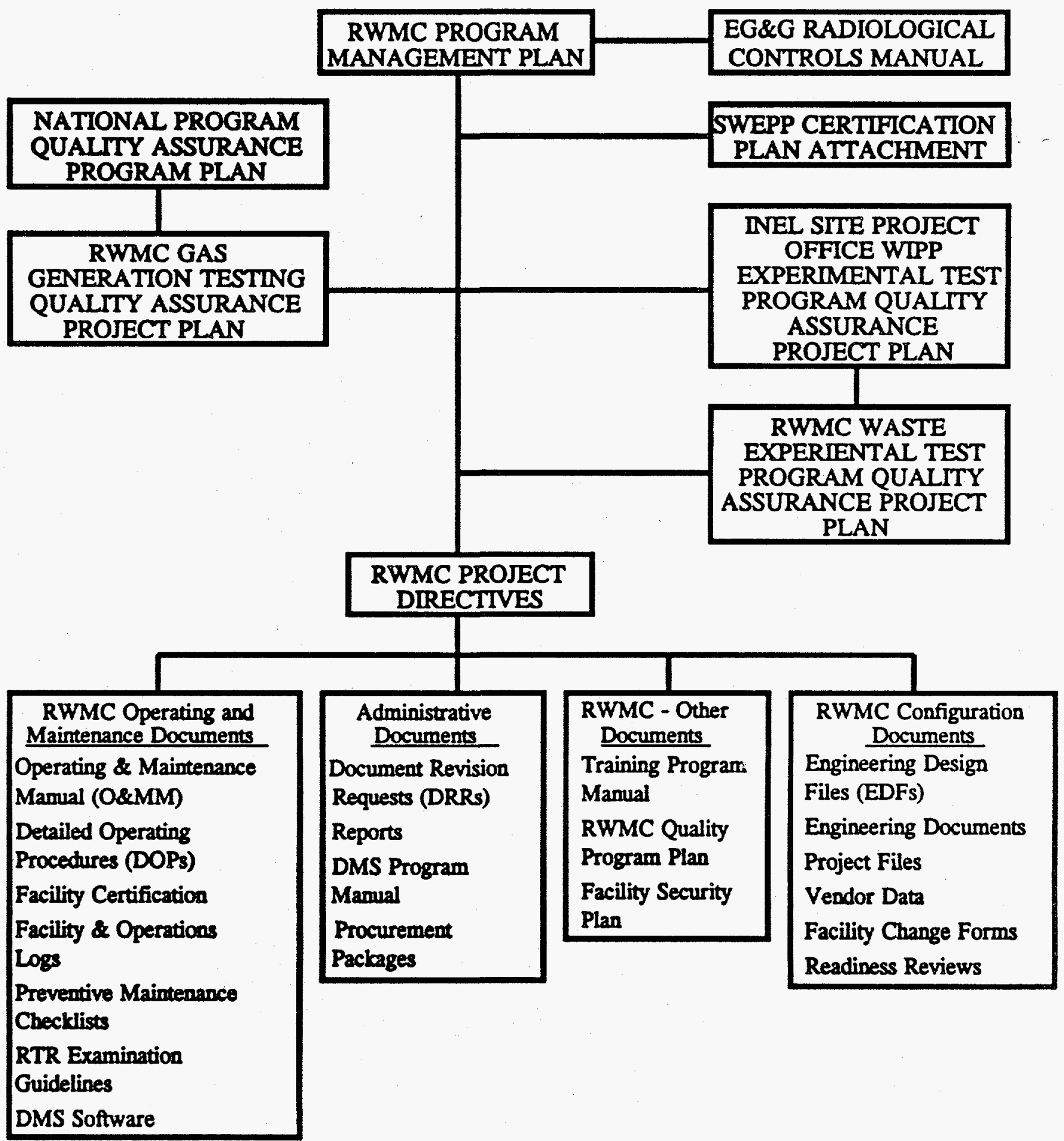

Figure 1. Document flow diagram. 


\subsubsection{Review and Approval of Documents}

Document review and approval requirements are specified in RWMC PD-RS-1.24, "Reviews of RWMC Documents," which establishes the policy by which document review and approval shall be performed. Prior to use, all quality assurance (QA) documents for the Program shall be formally reviewed and approved. Whenever these documents are revised, the same level of review and approval shall be required for the revised sections as for the originals.

At a minimum, this QAPjP shall be initially reviewed and approved by appropriate INEL Program and Department of Energy-Idaho Operations Office (DOE-ID) personnel. Thereafter, this QAPjP shall be reviewed at least annually at each site by the personnel indicated in Table 1. The INEL Gas Generation Testing Program manager is responsible for scheduling and coordinating the review and approval of the document. SOPs and DOPs are reviewed and approved in accordance with RWMC PD-RS-1.24.

\subsubsection{Document Control}

The INEL Gas Generation Testing Program manager shall be responsible for implementing this QAPjP. This QAPjP shall be controlled and distributed by the document control officer.

\subsubsection{Change Control}

Changes from originally approved documents, procedures, and specifications are anticipated because the Program is experimental in nature. A change does not necessarily imply nonconformance, but rather reflects the progress of the project in incorporating information that best meets Program objectives. The Document Revision Request (Form EG\&G-1844) system shall be used to document and authorize changes to RWMC documents. Directions regarding document change control are set forth in RWMC PD-RS-1.13, "Use of DOPs and SOPs," and in RWMC PD-RS-1.24, "Reviews of RWMC Documents."

Table 1. Document review matrix for the INEL Gas Generation Testing Program QAPjP.

\begin{tabular}{|c|c|c|c|c|c|c|}
\hline & $\begin{array}{c}\text { INEL Gas } \\
\text { Generation } \\
\text { Testing Program } \\
\text { manager }\end{array}$ & $\begin{array}{l}\text { TRU Waste } \\
\text { Programs } \\
\text { unit managet }\end{array}$ & $\begin{array}{l}\text { RWMC } \\
\text { manager }\end{array}$ & $\begin{array}{l}\text { RWMC } \\
\text { quality } \\
\text { engineer }\end{array}$ & $\begin{array}{c}\text { RWMCSSWEPP } \\
\text { operations } \\
\text { manager }\end{array}$ & $\begin{array}{l}\text { DOE-ID } \\
\text { Operations } \\
\text { Office }\end{array}$ \\
\hline Create & $\mathbf{x}$ & - & - & - & - & - \\
\hline Review & $\mathbf{x}$ & $\mathbf{x}$ & $\mathbf{x}$ & $\mathbf{x}$ & $\mathbf{x}$ & $x$ \\
\hline Approve & $x$ & $x$ & $\mathbf{x}$ & $x$ & - & $\mathrm{x}$ \\
\hline Implement & $\mathbf{x}$ & - & - & - & - & - \\
\hline Change review & - & - & - & - & $\mathbf{x}$ & $\mathbf{x}$ \\
\hline $\begin{array}{l}\text { Change } \\
\text { approval }\end{array}$ & $\mathbf{x}$ & $\mathbf{x}$ & $\mathbf{x}$ & $\mathbf{x}$ & - & - \\
\hline Change control & $\mathbf{x}$ & - & - & - & - & - \\
\hline
\end{tabular}


As a minimum, revisions to documents shall be identified by including the current revision number on the document title page, the revised signature page, and each page that has been revised. Only revised pages need to be reissued. A revision bar (a vertical line along the margin of a page) may also be used to clearly indicate where revisions have been made.

\subsection{Quality Assurance Records}

This section specifies the requirements and responsibilities for transmitting, distributing, retaining, maintaining, and disposing of quality records according to DOE Order 5700.6C (DOE 1991a). These requirements are implemented through EG\&G Idaho Quality Manual QP-17 and RWMC PD-RS-1.33, "Records Management," which establishes policy requirements, responsibilities, and procedures for records management at the RWMC, including responsibilities for recordkeeping and maintenance, protection, issuance and retrieval, transfer, and disposition of records.

The INEL WETP site document control officer shall be the document control officer for this Program. Program files at the INEL are maintained by the document control officer. All QA and quality control $(Q C)$ records associated with the Program will be considered Lifetime Records as defined in NQA-1, Supplement 17S-1 [American Society of Mechanical Engineers (ASME, 1989)], and shall be maintained for the active life of the WIPP facility. Record control shall include receipt from external sources, transmittal, transfer to storage, and indication of record status.

\subsubsection{Central Files}

Signed originals, copies of data, or information developed from activities and laboratory analyses associated with the Program shall be sent to the Gas Generation Testing Program Integrated Working Group (IWG) coordinator, who shall maintain all the Program information in a central file. Copies of records shall be maintained, as necessary, at the INEL by the document control officer.

The document control officer is responsible for records administration for this Program at the INEL, and shall notify the INEL Gas Generation Testing Program manager and QA personnel of status changes in Program documents, including reporting formats or procedures. Outdated or superseded documentation shall not be used; however, one copy of voided documents shall be maintained in Program files, along with the reasons for the void and date of implementation.

\subsubsection{Record Retention}

A record of all documents or records transmitted to the DOE Carlsbad Area Office (CAO) shall be kept by the document control officer. At a minimum, files sent to the DOE/CAO shall include the following:

- Summary reports of data 
- Audit plans, checklists, reports, responses, and closures

- QA reports to management

- Program correspondence.

\subsubsection{Laboratory Files}

The Environmental Chemistry Laboratory (ECL) shall maintain a records management system for all applicable quality-related documents consistent with the requirements specified in this QAPjP and the Program Quality Assurance Program Plan (QAPP).

\subsection{Procurement Document Control/Control of Subcontractors}

The design bases and other requirements necessary to ensure adequate quality shall be included or referenced in procurement documents for any equipment and services affecting quality.

\subsubsection{Procurement Document Control}

When necessary, procurement documents shall require suppliers of equipment or analytical services to have a QA program that meets or exceeds the applicable criteria of this document and the Program QAPP. If suppliers do not have a QA program that addresses these requirements, applicable requirements will be specified in procurement documents.

Procurement document control and control of purchased material and services at the RWMC shall be in strict compliance with the requirements set forth in the RWMC Quality Program Plan. The specific procedures that implement these requirements are ider. .ied in the Quality Program Index contained in the RWMC Quality Program Plan.

\subsubsection{Control of Subcontractors}

All subcontractors involved with the Program must be made aware of performance requirements. Performance and compliance requirements documented in this QAPjP shall be included as part of subcontractor agreements. Each subcontractor shall, as necessary, complete training required for implementing the QAPjP. If necessary, prequalification audits may be performed by QA personnel to determine subcontractor acceptability. Subcontractors shall be required to complete and submit copies of project-related records to the INEL Gas-Generation Testing Program manager.

Subcontractor-prepared documentation may be evaluated or audited to verify compliance with Program quality requirements. Subcontractors shall provide access to their work areas and records for inspection and auditing. Inspections, audits, and corrective action shall be performed in accordance with the requirements of Sections 11 and 14 of this document. 


\subsubsection{Control of Purchased Items and Services}

The procurement of items and services shall be controlled to ensure conformance with specified requirements. Controls may include evaluating selected services or equipment; reviewing and evaluating the quality provided by the supplier; and inspecting, auditing, and examining items or services upon delivery or completion.

The purchase, use, or design modifications to all equipment and replacement parts used for the Program shall be documented and controlled. Documents traceable to these activities must be maintained as a part of the Program files.

\subsubsection{Identification and Control of Items}

Identification of accepted items shall be maintained in documents traceable to the items, or in a manner that ensures that identification is established and maintained. Identification and traceability methods may include item identification, from initial receipt up to and including installation and use, physical identification, clear and legible marking, or any combination thereof. Items that have a limited calendar or operating life shall be identified and controlled to preclude their use once their shelf life or operating life has expired.

RWMC identifies and controls items in accordance with NQA-1, Element 8, through use of procedures identified in the Quality Program Index contained in the RWMC Quality Program Plan.

\subsubsection{Control of Processes}

Processes affecting quality of items or services shall be controlled. Special processes that coatrol or verify quality shall be performed by qualified personnel using approved procedures in accordance with specified requirements.

\subsection{Personnel Qualification and Training}

As specified in NQA-1, Element 2, all personnel performing activities affecting quality shall be indoctrinated and trained so they will achieve and maintain suitable proficiency in their job functions. Personnel involved with this project shall be qualified to perform their functions by virtue of education, experience, and training applicable to the work. Objective evidence of personnel proficiency shall be demonstrated and documented.

Specific training may be waived by line management if the individual can demonstrate proficiency in the activity to be performed. Demonstration of proficiency without training must also be documented in writing. All training records that specify the scope of training, date of completion, and participants shall be maintained or referenced as project records.

Employees shall receive training requisite with activities and levels of responsibility. Requirements for training RWMC personnel are set forth in the RWMC Training Manual and in the Waste Management Department Training Program Manual. The RWMC Training Unit ensures 
development, approval, and maintenance of the RWMC Training Manual and the Waste Management Department Training Program Manual. The unit identifies training requirements for RWMC personnel, facilitates scheduling, and ensures that facility personnel receive requisite training. The RWMC Training Unit maintains training records for all assigned personnel at the RWMC facility. Requirements for maintaining job proficiency and certification are included in the RWMC Training Manual or the Waste Management Department Training Program Manual.

Indoctrination and training for INEL WIPP Experimental Test Program (WETP) Site Project Office (SPO) personnel used for this Program (includes the data validation officer, quality assurance officer, and document control officer), are described in WETP-PD-1.8.

For ECL personnel participating in this Program, ECL SOP 1.1.3, "Personnel Training," describes the specific procedures followed for analyst training and for documenting the training.

\subsection{Analytical Laboratory (Environmental Chemistry Laboratory)}

The analytical laboratory ECL must have a documented laboratory QA plan in place that describes general QA procedures specific to the laboratory's normal operations. The ECL QA plan must meet or exceed the requirements of this QAPjP and the QAPP. 


\section{PROJECT ORGANIZATION AND RESPONSIBILITIES}

This section describes the project organization and demonstrates that it is adequate to accomplish project goals and ensure that all responsibilities have been assigned. An organization chart is provided in Figure 2 . The frequency and mechanisms of communications are described.

\subsection{INEL Gas Generation Testing Program Manager}

The INEL Gas Generation Testing Program manager is responsible for all aspects of this Program at the INEL. Specific responsibilities of the INEL Gas Generation Testing Program manager include the following:

- Transmit data to the Gas Generation Testing IWG coordinator.

- Develop site-specific documents (DOPs, SOPs, etc.) detailing how this QAPjP is implemented

- Review and approve this QAPjP and ensure its review annually thereafter

- Review this QAPjP and affected SOPs as a result of changes in the QAPP

- If changes to this QAPjP are required, schedule and coordinate the review and approval of the revised document

- Report all changes in this QAPjP to the Gas Generation Testing Program IWG coordinator and to DOE-ID

- Notify appropriate personnel of changes to this QAPjP

- Notify project personnel and DOE-ID of nonconformances

- Send quality-related information report to DOE-ID

- Monitor and control the status of work and Program activities at the INEL

- Obtain project-related records from subcontractors

- Ensure that changes in obsolete or superseded Program-related information are reflected in all records transmitted to the Gas Generation Testing Program IWG coordinator.

\subsection{Quality Assurance Officer}

The INEL WETP site quality assurance officer will serve as the quality assurance officer for this Program. This quality assurance officer is responsible for ensuring that all QA requirements related to this Program are met and that this document is implemented. The quality assurance 


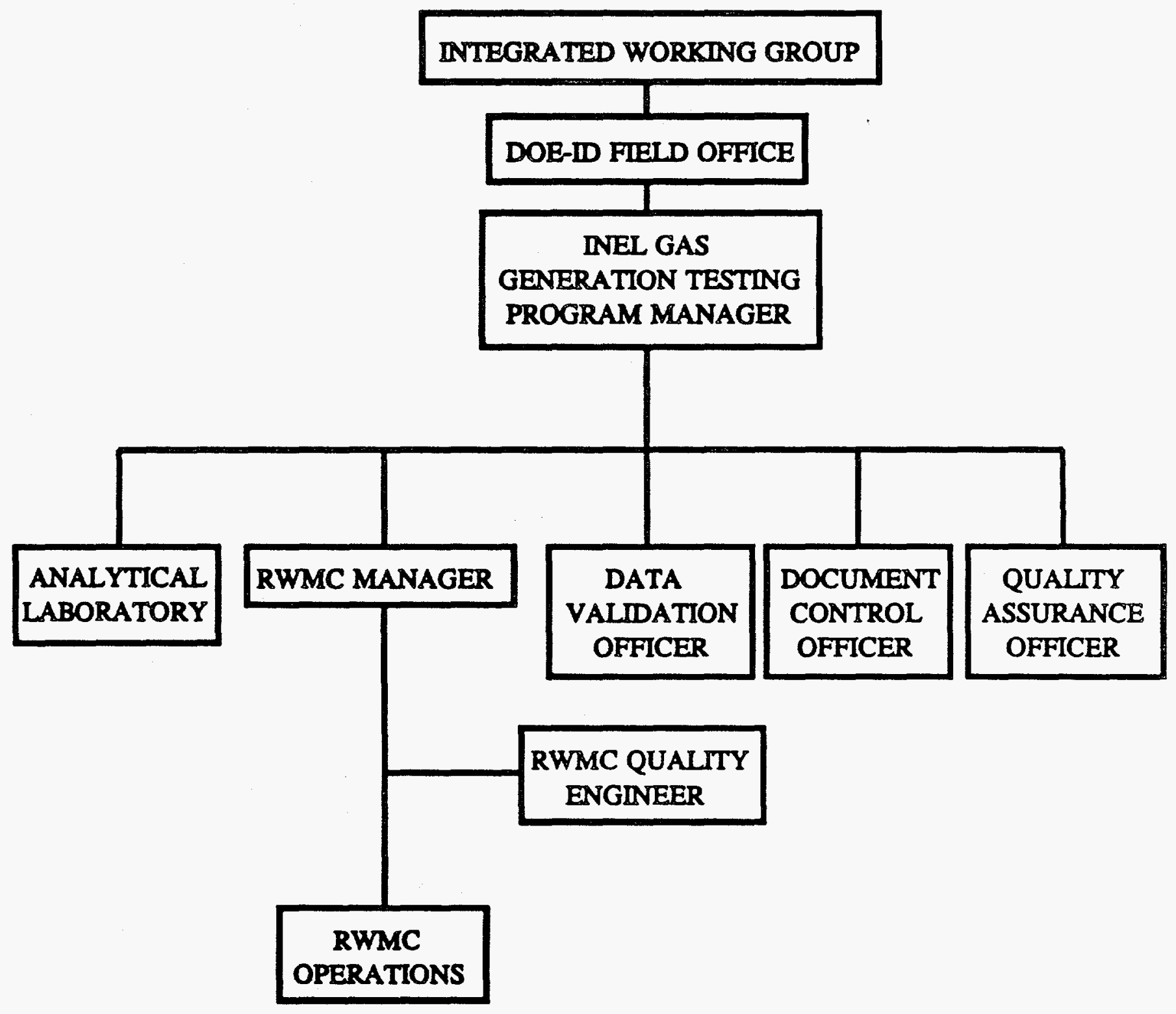

Figure 2. INEL Gas Generation Testing Project functional orgainzation diagram. 
officer shall provide day-to-day guidance on quality-related matters, as necessary, to Program staff. Specific duties of the quality assurance officer for this Program shall include the following:

- Implement procedures for the review and approval of the analytical laboratory QA plans

- Verify supplier compliance with applicable quality requirements

- Schedule and conduct periodic internal audits of Program activities

- Report results of internal audits to the INEL Gas Generation Testing Program manager

- Assess the significance of any variances and determine what notifications are required

- Establish a written procedure for reporting obsolete information

- Conduct prequalification audits to determine subcontractor acceptability.

\subsection{RWMC Quality Engineer}

The RWMC quality engineer shall provide independent review of procedures and activities related to quality and shall provide input regarding the latest quality requirements. The RWMC quality engineer is responsible for reviewing this QAPjP, any changes to this QAPjP, all new procedures, procedure changes, and procurement requisitions for proper quality requirements. The RWMC quality engineer verifies that all RWMC and SWEPP QA requirements are implemented. The RWMC quality engineer shall also review and evaluate all nonconformances, and shall verify that corrective actions to such are implemented.

\subsection{Data Validation Officer}

The INEL WETP site data validation officer shall also function as the data validation officer for the INEL Gas Generation Testing Program. This data validation officer shall be responsible for the following project-related activities:

- Reduce data as indicated in Section 9

- Collect, validate, and transmit data to the Gas Generation Testing IWG coordinator.

\subsection{Document Control}

The WETP site document control officer shall be the document control officer for this Program. The responsibilities of the document control officer for this Program shall include the following: 
- Keep a record of all documents or records transmitted to the IWG coordinator and the DOE/CAO

- Implement document control procedures

- Maintain a records management system for all information related to this Program

- Provide adequate control and retention of all Program-related information

- Ensure that systems are in place for retaining records, including receipt at the record storage areas, indexing, filing, storage, maintenance, and retrieval

- Notify Program personnel of status changes in Program documents, such as reporting formats or procedures

- Maintain a system for ensuring that outdated or superseded data are not used.

\subsection{Operations Personnel}

The RWMC manager is responsible for the safe completion of activities for this project at the SWEPP facility. The RWMC manager is responsible for all operations and equipment used during the project, and for providing trained operations personnel for the Program.

The RWMC Operations Unit implements and complies with plant operating procedures and controls to ensure proper and safe operation of the plant under all operating conditions, conducts periodic maintenance and repairs on plant equipment, and ensures that safe conditions exist in the plant under all operating modes.

Responsibilities of personnel include the following:

- Report obsolete or superseded Program-related information to the document control officer

- Perform activities using approved procedures in accordance with specified requirements. 


\section{QUALITY ASSURANCE OBJECTIVES}

Data quality is represented in terms of precision, accuracy, representativeness, completeness, and comparability.

Precision and accuracy are quantitative measures that characterize the variability and bias inherent in a given data set. Precision refers to the level of agreement among repeated measurements of the same characteristic. Precision may be expressed as the relative percent difference (RPD) between duplicate measurements or as the percent relative standard deviation (\%RSD) between replicate measurements. Accuracy refers to the degree to which the data agree with the true or known value of the parameter being measured. Accuracy may be expressed as percent recovery $(\% \mathrm{R})$. The $\% \mathrm{R}$ is the ratio of the measured value to the true or known value and is expressed as a percentage.

Representativeness is used to convey the degree to which a sample exhibits average properties of the waste. Representativeness is usually achieved by collecting enough samples or ensuring that the samples collected are large enough to be representative. At other times, representativeness is attained by collecting samples close to the point of origin of the element to be sampled.

Completeness refers to the amount of data that are successfully collected with respect to the amount intended in the experimental design. A certain percentage of the intended amount of data must be successfully collected in order for the conclusions that are based on the data to be valid. For example, when completeness is expressed as being $90 \%, 90 \%$ of the minimum required data points have been collected. Completeness is important because missing data may lower the level of confidence in the conclusions.

Comparability refers to the similarity of data from different sources included in a single data set. If more than one team collects samples or more than one laboratory analyzes the samples, they must use procedures that provide data that meet the same data quality objectives. Comparability may also be achieved using similar field reference standards.

Section 13 presents the equations used to calculate the precision, accuracy, completeness, and method detection limits.

\subsection{Gas Sampling}

Gas sampling shall be performed using the procedures described in DOP RO 4.3.7.

\subsubsection{Precision}

For VOC samples, the precision of sampling operations will be measured by taking duplicates and by calculating the RPD. 


\subsubsection{Accuracy}

A sampling calibration standard will be used to assess the accuracy of sampling operations. The calibration gas will be introduced into the system prior to the flow measurement device (or equivalent device) and will be analyzed for composition after the gas sampling connector. The \% $\mathrm{R}$ will be calculated and reported as a result of this analysis.

\subsubsection{Representattveness}

The following strategies shall be used to ensure the representativeness of the gas sampling: (1) cleaning and leak testing of sampling syringes, canisters, or other sampling equipment, and (2) sample size selection.

\subsubsection{Completeness}

All of the drums used in the test procedure will be involved in sampling operations.

\subsubsection{Comparability}

Gas sampling comparability among different sampling teams will be measured through the use of calibration standard gases. To evaluate comparability, the standards will be analyzed to the same degree of accuracy and precision.

\subsection{Gas Flow Measurements}

The quality of flow measurement data is determined from the flow measurement device. Hydrogen/methane gas concentrations and the total gas flow rate will be used to calculate the hydrogen/methane generation rate. Table 2 summarizes the quality assurance objective, for gas llow rate measurements.

\subsubsection{Precision}

The precision of flow-rate measurement devices may be determined at the time of calibration. The acceptable precision range for flow-rate measurements is $\pm 2.0 \%$ of instantaneous measurements.

\section{2 .2 Accuracy}

The acceptable flow-rate accuracy range is $\pm 5.0 \%$ of instantaneous measurements. The accuracy of the gas flow-rate measurements will be verified by frequent equipment calibration checks.

Table 2. Quality assurance objectives for gas flow rate measurements.

\begin{tabular}{lccc}
\hline Parameter & Precision & Accuracy & Completeness \\
\hline Gas flow rate & $\pm 2.0 \%$ & $\pm 5.0 \%$ & $90 \%$ \\
\hline
\end{tabular}




\subsubsection{Representativeness}

Representativeness of flow rate shall be ensured through the following activities:

- Taking measurements in a location close to the exit of the 55-gal drum

- Making temperature and barometric pressure corrections, as necessary.

\subsubsection{Completenese}

Ninety percent of the expected minimum number of gas flow measurements must be reported.

\section{2 .5 Comparability}

Comparability of flow rate measurement will be ensured by using flow-rate measurement devices that have been calibrated against nationally accepted standards.

\subsection{Hydrogen/Methane Gas Analysis}

The hydrogen/methane concentration will be measured using an on-line mass spectrometer. The method detection limit (MDL) is 0.1 volume percent (see Section 13.4 for the definition of $\mathrm{MDL}$ ). The quality assurance objectives for hydrogen/methane gas analyses are summarized in Table 3.

\subsubsection{Precision}

Acceptable precision for the hydrogen/methane analyses is $\pm 10 \%$. The assessment of precision of the on-line mass spectrometer will be evaluated during cold testing.

\subsubsection{Accuracy}

The acceptable range of accuracy for the hydrogen/methane analyses is $\pm 10 \%$. The accuracy level for these analyses will be measured through the use of calibration standard gases.

\subsubsection{Representatheneas}

Placing the process mass spectrometer (or equivalent instrumentation) as close as possible to the flow measurement device outlet will ensure representativeness.

\subsubsection{Completeness}

Completeness for hydrogen/methane concentration data must be at least $90 \%$.

\subsubsection{Comparability}

Comparability will be ensured through the use of calibration standard gases. 
Table 3. Quality assurance objectives for hydrogen/methane concentration measurements.

\begin{tabular}{lcccc}
\hline Compound & $\begin{array}{c}\text { Precision } \\
\text { (\%RSD or RPD) }\end{array}$ & Accuracy & MDL & Completeness \\
\hline Hydrogen & $\pm 10 \%$ & $\pm 10 \%$ & 0.1 vol\% & $90 \%$ \\
Methane & $\pm 10 \%$ & $\pm 10 \%$ & 0.1 vol\% & $90 \%$ \\
\hline
\end{tabular}

\subsection{Volatile Organic Compound Analyses}

The concentration of VOCs from the target compound list that are present within the drum headspace will be measured using an on-line mass spectrometer. The target compound list and quality assurance objectives for VOCs are provided in Table 4.

\subsubsection{Precision}

Precision may be assessed through the use of laboratory duplicates and replicate analyses of laboratory control or blind samples. The acceptable range of precision for the flammable VOCs is $\pm 25 \%$.

\subsubsection{Accuracy}

VOC analysis accuracy is expressed as percent recovery; the acceptable range is $\pm 30 \%$.

\subsubsection{Representativeness}

VOC sample representativeness will be ensured by the proximity of the gas sampling connector to the top of the drum. Proper selection of sample size will also contribute to attainment of this goal.

\subsubsection{Completeness}

The VOC completeness quality assurance objective is $90 \%$ of all data reports filed.

\subsubsection{Comparability}

To ensure comparability, samples will be taken at ambient temperature before the test procedure is initiated, under the same sampling conditions as those for the WIPP Experimental Waste Characterization Program. This will ensure that evaluation of compliance with the limit on flammable VOCs will be made under a consistent set of conditions.

\subsection{Mass Balance Parameters}

The relative humidity, $\mathrm{O}_{2}, \mathrm{~N}_{2}, \mathrm{CO}_{2}$, and $\mathrm{Ar}$ will be measured with an on-line mass spectrometer to estimate various other components in the offgas. These parameters will be investigated only for mass balance purposes. The quality assurance objectives for the mass balance parameters are given in Table 5. 
Table 4. Quality assurance objectives for VOCs in headspace gases.

\begin{tabular}{|c|c|c|c|c|}
\hline Compound & $\begin{array}{l}\text { Precision } \\
\text { (\%RSD or } \\
\text { RPD) }\end{array}$ & $\begin{array}{c}\text { Accuracy } \\
(\% \mathrm{R})\end{array}$ & $\begin{array}{c}\text { MDL } \\
\text { (ng) }\end{array}$ & Completeness \\
\hline Benzene" & $\pm 25 \%$ & $\pm 30 \%$ & 8 & $90 \%$ \\
\hline Bromoform & $\pm 25 \%$ & $\pm 30 \%$ & 8 & $90 \%$ \\
\hline Carbon tetrachloride & $\pm 25 \%$ & $\pm 30 \%$ & 8 & $90 \%$ \\
\hline Chlorobenzene $^{2}$ & $\pm 25 \%$ & $\pm 30 \%$ & 8 & $90 \%$ \\
\hline Chloroform & $\pm 25 \%$ & $\pm 30 \%$ & 8 & $90 \%$ \\
\hline Cyclohexane $e^{2}$ & $\pm 25 \%$ & $\pm 30 \%$ & 8 & $90 \%$ \\
\hline 1,1-dichloroethane & $\pm 25 \%$ & $\pm 30 \%$ & 8 & $90 \%$ \\
\hline 1,2-dichloroethane & $\pm 25 \%$ & $\pm 30 \%$ & 8 & $90 \%$ \\
\hline 1,1-dichloroethene & $\pm 25 \%$ & $\pm 30 \%$ & 8 & $90 \%$ \\
\hline cis-1,2-dichloroethene & $\pm 25 \%$ & $\pm 30 \%$ & 8 & $90 \%$ \\
\hline Ethyl benzene ${ }^{\mathbf{a}}$ & $\pm 25 \%$ & $\pm 30 \%$ & 8 & $90 \%$ \\
\hline Ethyl ether & $\pm 25 \%$ & $\pm 30 \%$ & 8 & $90 \%$ \\
\hline Methylene chloride & $\pm 25 \%$ & $\pm 30 \%$ & 8 & $90 \%$ \\
\hline 1,1,2,2-trichloroethane & $\pm 25 \%$ & $\pm 30 \%$ & 8 & $90 \%$ \\
\hline Tetrachloroethene & $\pm 25 \%$ & $\pm 30 \%$ & 8 & $90 \%$ \\
\hline Toluene & $\pm 25 \%$ & $\pm 30 \%$ & 8 & $90 \%$ \\
\hline 1,1,1-trichloroethane & $\pm 25 \%$ & $\pm 30 \%$ & 8 & $90 \%$ \\
\hline Trichloroethene & $\pm 25 \%$ & $\pm 30 \%$ & 8 & $90 \%$ \\
\hline 1,1,2-trichloro-1,2,2-trifluoroethane & $\pm 25 \%$ & $\pm 30 \%$ & 8 & $90 \%$ \\
\hline 1,2,4-trimethylbenzene & $\pm 25 \%$ & $\pm 30 \%$ & 8 & $90 \%$ \\
\hline 1,3,5-trimethylbenzene" & $\pm 25 \%$ & $\pm 30 \%$ & 8 & $90 \%$ \\
\hline o-xylene & $\pm 25 \%$ & $\pm 30 \%$ & 8 & $90 \%$ \\
\hline m-xylene $e^{2}$ & $\pm 25 \%$ & $\pm 30 \%$ & 8 & $90 \%$ \\
\hline p-xylene" & $\pm 25 \%$ & $\pm 30 \%$ & 8 & $90 \%$ \\
\hline Acetone & $\pm 25 \%$ & $\pm 30 \%$ & so & $90 \%$ \\
\hline n-butanol & $\pm 25 \%$ & $\pm 30 \%$ & 50 & $90 \%$ \\
\hline 2-butanone & $\pm 25 \%$ & $\pm 30 \%$ & 50 & $90 \%$ \\
\hline Methanol & $\pm 25 \%$ & $\pm 30 \%$ & 50 & $90 \%$ \\
\hline 2-methyl-2-pentanone & $\pm 25 \%$ & $\pm 30 \%$ & 50 & $90 \%$ \\
\hline
\end{tabular}

a. Flammable VOCs. 
Table 5. Quality assurance objectives for mass balance parameter measurements.

\begin{tabular}{lcccc}
\hline \multicolumn{1}{c}{ Parameter } & Precision & Accuracy & MDL & Completeness \\
\hline Relative humidity & $\pm 10 \%$ & $\pm 10 \%$ & 1.0 vol\% & $90 \%$ \\
$\mathrm{~N}_{2}$ & $\pm 10 \%$ & $\pm 10 \%$ & $1.0 \mathrm{vol} \%$ & $90 \%$ \\
$\mathrm{O}_{2}$ & $\pm 10 \%$ & $\pm 10 \%$ & $1.0 \mathrm{vol} \%$ & $90 \%$ \\
$\mathrm{CO}_{2}$ & $\pm 10 \%$ & $\pm 10 \%$ & $1.0 \mathrm{vol} \%$ & $90 \%$ \\
$\mathrm{Ar}$ & $\pm 10 \%$ & $\pm 10 \%$ & $1.0 \mathrm{vol} \%$ & $90 \%$ \\
\hline
\end{tabular}

\subsubsection{Precision}

The acceptable precision range for relative humidity, $\mathrm{O}_{2}, \mathrm{~N}_{2}, \mathrm{CO}_{2}$, and $\mathrm{Ar}$ is $\pm 10 \%$.

\subsubsection{Accuracy}

The quality assurance objective for the percent accuracy of relative humidity, $\mathrm{O}_{2}, \mathrm{~N}_{2}, \mathrm{CO}_{2}$, and $A r$ is $\pm 10 \%$.

\subsubsection{Representativeness}

Representativeness is achieved by taking samples throughout the test procedure simultaneously with sampling for other compounds.

\subsubsection{Completeness} is $90 \%$.

The completeness goal for the measurement of relative humidity, $\mathrm{O}_{2}, \mathrm{~N}_{2}, \mathrm{CO}_{2}$, and $\mathrm{Ar}$

\subsubsection{Comparability}

Comparability of data is ensured by using quality assurance objectives common to the WIPP Experimental-Waste Characterization Program for $\mathrm{O}_{2}, \mathrm{~N}_{2}, \mathrm{CO}_{2}$ and Ar.

\subsection{Other Variables}

Temperature and barometric pressure are important to the data collection activities and may have less restrictive quality assurance objectives.

\subsubsection{Temperature}

All gas measurements for the test are dependent upon temperature. Temperature will be measured using type $\mathrm{K}$ thermocouples on the outside of the drum and at the point of sampling (i.e., just upstream of the flow measurement device). Temperature data precision will be recorded during the calibration of all temperature instruments and is expected to be within \pm 1 degree Fahrenheit $\left({ }^{\circ} \mathrm{F}\right)$. The quality assurance objective for temperature measurement accuracy is $\pm 2^{\circ} \mathrm{F}$. 
To achieve representativeness with respect to the temperature of the offgas, temperature measurements will be taken as close to the gas sampling connector (outside the drum) as possible. The location at which the drum temperature is taken will be determined during cold testing. Temperature measurements should be obtained for all of the samples taken during the test procedure. The completeness quality assurance objective for temperature measurements is $90 \%$. Temperature measurement comparability will be achieved through the use of thermometers or thermocouples that are of the required precision and accuracy. The quality assurance objectives for temperature measurements are summarized in Table 6.

\subsubsection{Barometric Pressure}

Barometric pressure will be measured at the location of the tests using an electronic barometer that continuously transmits the local barometric pressure directly to the data acquisition system. Precision and accuracy are expected to be \pm 0.1 in. of mercury.

Table 6. Quality assurance objectives for temperature measurements.

\begin{tabular}{cccc}
\hline Parameter & Precision & Accuracy & Completeness \\
\hline Temperature & $\pm 1.0^{\circ} \mathrm{F}$ & $\pm 2.0^{\circ} \mathrm{F}$ & $90 \%$ \\
\hline
\end{tabular}




\section{WASTE CONTAINER SELECTION AND PRETEST CHARACTERIZATION}

Waste containers are selected to ensure compliance with all transportation requirements related to the TRUPACT-II shipping container and to the TRAMPAC. Each container shall undergo real-time radiography (RTR) and radioassay (RA) to calculate the decay heat of the waste container. The criteria used to select the containers used in the Program are given in Table ?.

All drums selected for this Program must be certified to meet the WIPP WAC. Non-WIPPcertifiable drums of waste will not be included in this Program. RWMC PD-RS-2.10, "Documentation of Waste Certification," defines the process of certification and the requirements for documentation of waste certification. Certified waste is defined as waste that meets all of the WIPP certification criteria as defined in DOE-WIPP-069 (TRU Waste Acceptance Criteria for the Waste Isolation Pilot Plant).

Drums of waste to be used for the Gas Generation Testing Program will be randomly selected from the population of drums that meet the requirements of this Program, as defined in the Program QAPP. 
Table 7. Decay heat criteria for drum selection.

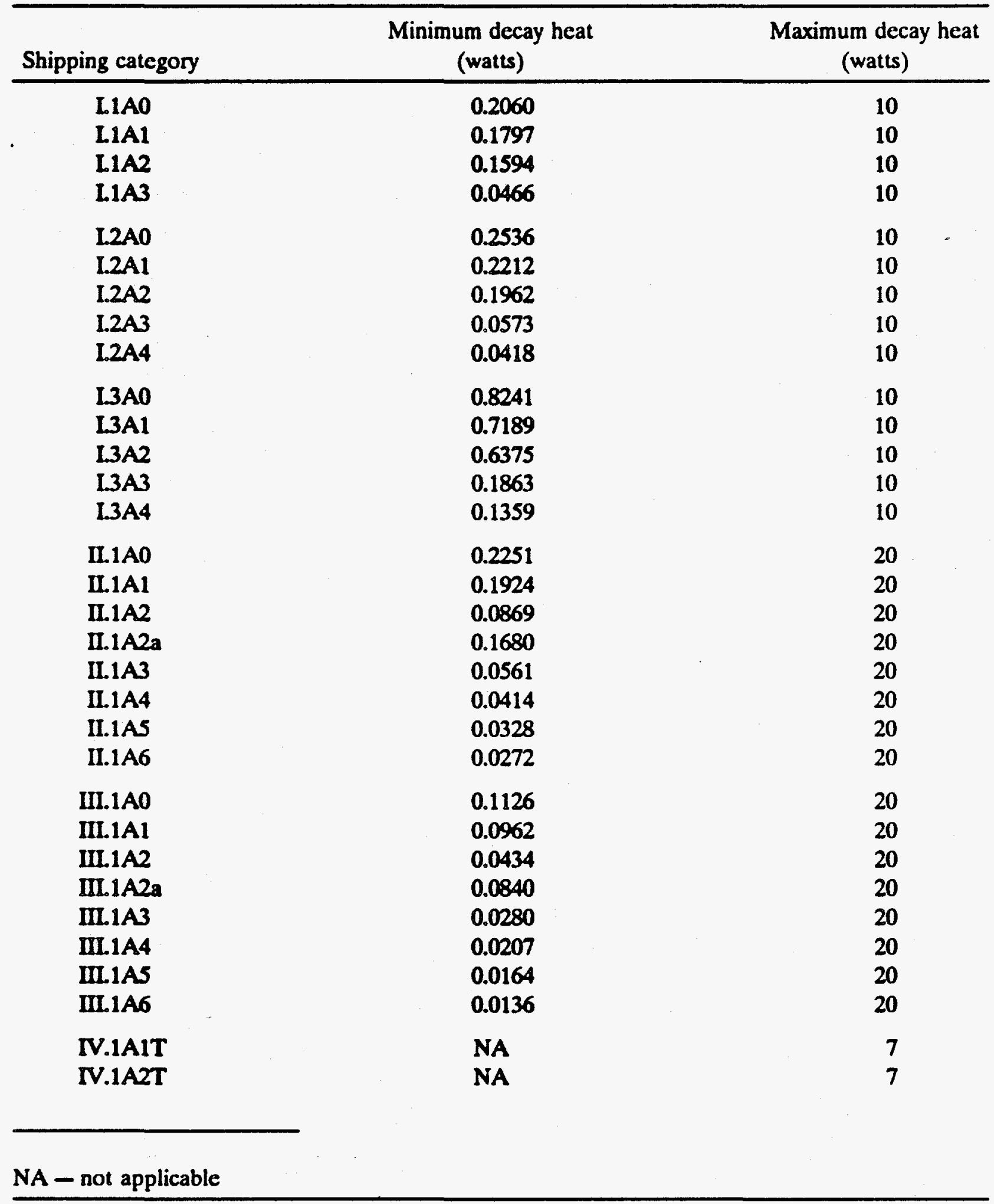




\section{SAMPLING PROCEDURES}

This section describes the sampling requirements.

\subsection{Sampling Protocol}

Prior to sampling, the 55-gal drums of CH-TRU waste shall be transferred to the test area in the SWEPP. Samples of drum headspace will be collected at ambient temperature. SUMMA canisters may be used to collect VOC samples to maintain the data comparability between this Program and the WIPP Experimental-Waste Characterization Program, and to verify that the mass spectrometer provides accurate analyses as part of its qualification procedure. Table 8 presents the containers, sample volume required, holding temperature, and maximum holding time for VOC samples collected in SUMMA canisters.

Drums are connected to the sampling manifold in accordance with a site work releasc (SWR) prepared for each drum. Figure 3 presents a schematic of the test setup. The system used to measure the gas flow consists of a flow measurement device and associated electronics.

Samples will be collected through the test setup sample manifold and will be analyzed using an on-line mass spectrometer. Sample analysis results are recorded directly on the hard disk of the computer that operates the mass spectrometer and controls the sampling process. Program support personnel (e.g., Health Physies and Operations) will monitor the sampling process.

\subsection{Sampling Manifold Cleaning}

Prior to each drum test, and upon completion of each testing episode, the sample manifold shall be purged and a sample blank shall be collected and analyzed to ensure that the manifold contains no contamination.

\subsection{Container Cleaning}

Any containers (SUMMA๑ canisters) used for sampling shall be thoroughly cleaned by the ECL in accordance with ECL SOP OP1.1, "SUMMA• Canister Cleaning."

Table 8. Sample containers and holding times for VOC sample collection.

\begin{tabular}{cccccc}
\hline Parameter & Container & $\begin{array}{c}\text { Minimum sample } \\
\text { volume }\end{array}$ & $\begin{array}{c}\text { Holding } \\
\text { temperature }\end{array}$ & $\begin{array}{c}\text { Field holding } \\
\text { time }^{\mathrm{a}}\end{array}$ & $\begin{array}{c}\text { Laboratory } \\
\text { holding } \\
\text { time }^{\mathrm{b}}\end{array}$ \\
\hline VOCs & $\begin{array}{l}\text { SUMMA } \\
\text { canister }\end{array}$ & $250 \mathrm{~mL}$ & $0-40^{\circ} \mathrm{C}$ & 4 days & 28 days
\end{tabular}

a. From time of sample collection to shipment.

b. This maximum holding time begins at the verified time of sample receipt. 


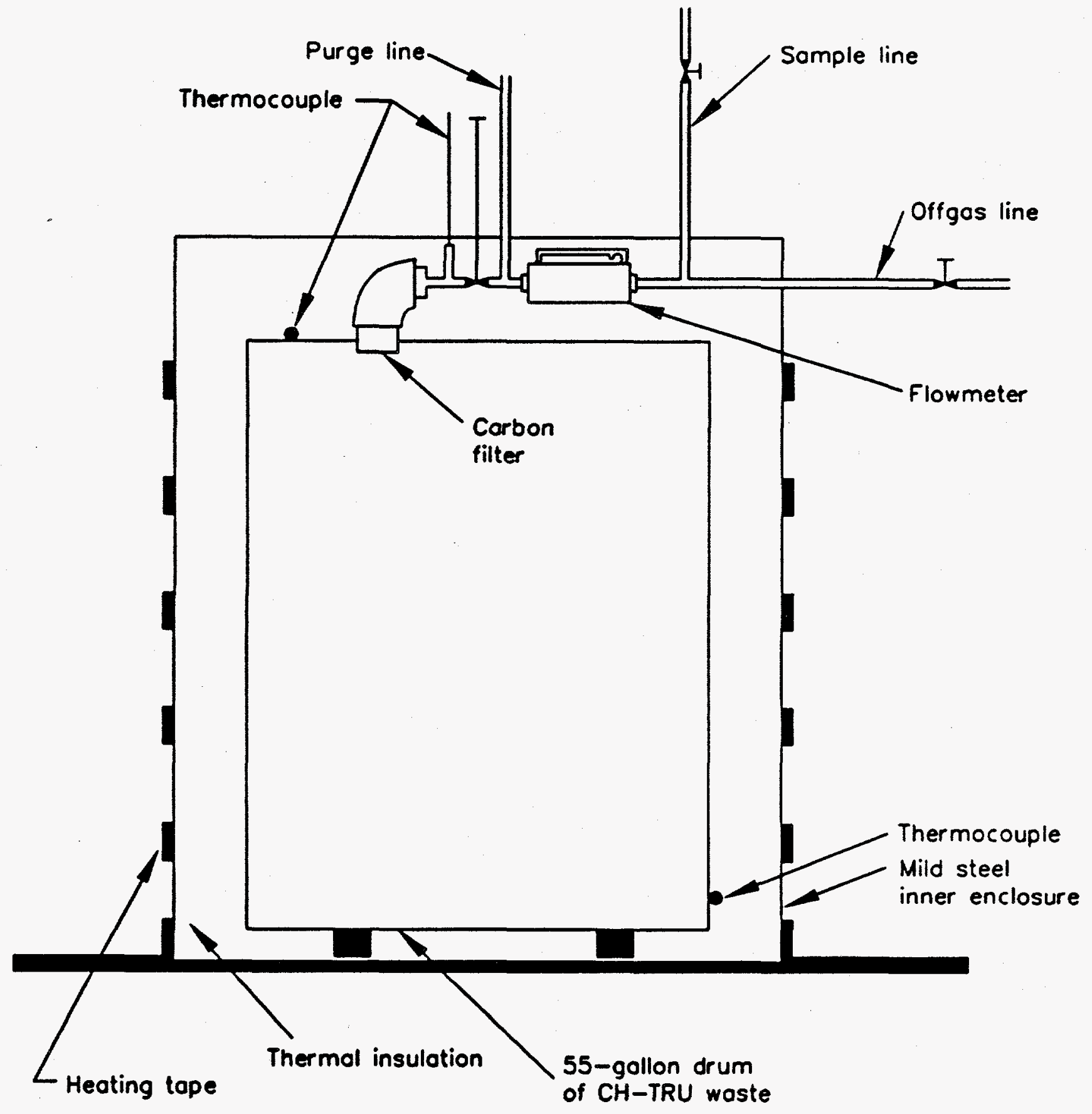

Figure 3. Test setap schematic. 


\section{SAMPLE CUSTODY}

Chain of custody (COC) shall be maintained and documented for any samples collected in SUMMA canisters (all other samples will be collected and analyzed on-line). COC of SUMMA canisters used for sampling shall be maintained through the entire sampling and analysis process. Whenever a transfer of custody takes place, both parties must sign and date the $C O C$ form, with the relinquishing organization retaining a copy of the form. The party that accepts custody must inspect the custody form and all accompanying documentation to ensure that the information is complete and accurate. The custodian must also inspect all samples for signs of damage or tampering. Any discrepancies in information or signs of damage or tampering must be documented on the $\mathrm{COC}$ form by the receiving custodian. The original $\mathrm{COC}$ form shall be maintained by the document control officer in the Program files. An example of the COC form is provided in Figure 4.

EG\&G Idaho's ECL will be used as the analytical laboratory. Samples will be shipped to ECL using INEL carriers. All SUMMA- canisters shall be surveyed for radioactivity before being shipped to the ECL. The surveying procedure ensures that sample canisters are classified correctly within U.S. Department of Transportation (DOT) and INEL packaging and shipping requirements.

COC for samples will be initiated when the samples (i.e., SUMMA canisters) are removed from the sampling manifold. COC on all samples taken shall be initiated immediately after sample collection or preparation using the sample canister COC form. Custody seals (Figure 5) shall be used on any analytical gas sample collected in a SUMMA canister as a tamper-indicating device. Sample custody shall be maintained until the associated analyses are completed and the data have been validated, as appropriate.

As each waste container is removed from the storage area, the existing har code label attached to the container is read with a portable barcode reader. The barcode label contains a number used to preclude container identification mistakes during examination and tracking in SWEPP. The barcode number is a unique six-digit barcode label that is attached to the drum for ease of identification while the container is stored at the SWEPP facility, and to ensure that all containers are uniquely identified.

Sample canister tags shall be used to document the physical existence and certified cleaning of a sample canister for the project file. A unique sample canister tag shall be included with each field sample canister provided. A sample canister tag (Figure 6) shall be affixed to the sample canister at the certifying laboratory, and shall remain attached during sample collection at the RWMC and subsequent laboratory analysis. These tags shall be used at the RWMC to certify that the canister has been leak tested, cleaned, and remains evacuated in transit from the laboratory to the RWMC, and to instruct the laboratory as to what analysis is required. The tags shall be completed and returned to the laboratory attached to the canister. 
Sempler:

Dotrinetion Laboratory:

Number of Semples:

Find Semple Numbers

\begin{tabular}{|l|l|l|l|l|}
\hline & & & & \\
\hline & & & & \\
\hline & & & & \\
\hline & & & & \\
\hline & & & & \\
\hline & & & & \\
\hline
\end{tabular}

\begin{tabular}{|c|c|c|c|c|}
\hline Location & Relinquished BY & Dere & nime & Recerved BY \\
\hline & & & & \\
\hline & & & & \\
\hline & & & & \\
\hline & & & & \\
\hline & & & & \\
\hline & & & & \\
\hline & & & & \\
\hline
\end{tabular}

Comments (note any discrepanciesl:

Completed by:

Dote: Time:

Figure 4. Example of a chain-of-custody form. 


\section{CUSTODY SEAL}

DATE

SIGNATURE

Figure 5. Example of a custody seal.

\section{WIPP GAS SAMPLE CANISTER TAG}
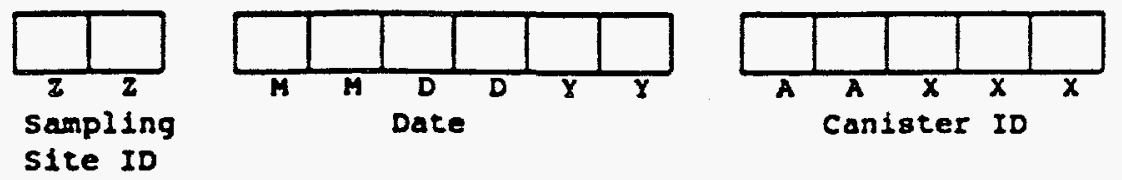

Bin Number:

Drum Number:

Sampling organization:

Sample Description:

\begin{tabular}{|c|c|c|c|c|c|}
\hline Location & $\begin{array}{r}\text { Canderer Preceure } \\
C \text { or } M \text { (1) }\end{array}$ & $\begin{array}{l}\text { Ambient } \\
P \text { and } T(2)\end{array}$ & $\begin{array}{r}\text { Date } \\
\text { MMDDYY }\end{array}$ & $\begin{array}{l}\text { Time } \\
24 \text { Hour }\end{array}$ & Initialo \\
\hline Cortltyang zaboratory & $\begin{array}{l}C= \\
M=\end{array}$ & $\begin{array}{l}P= \\
P=\end{array}$ & & & \\
\hline $\begin{array}{l}\text { Pielo- } \\
\text { Bafore Sample Collection }\end{array}$ & $\begin{array}{l}C= \\
M=\end{array}$ & $\begin{array}{l}\text { T= } \\
P=\end{array}$ & & & \\
\hline $\begin{array}{l}\text { Fiela- } \\
\text { afrer sample collection }\end{array}$ & $c=$ & $P=$ & & & \\
\hline Analgrical Laboratory & $\begin{array}{l}c= \\
M=\end{array}$ & Pa & & & \\
\hline Analyrical Laboratory & co & $T=$ & & & \\
\hline Analytieal zaboratory & $\begin{array}{l}c= \\
y=\end{array}$ & $\begin{array}{l}T= \\
P=\end{array}$ & & & \\
\hline
\end{tabular}

\section{ANAIYSIS REQUESTED}

\section{Inorganic Gases}

\begin{tabular}{|l|l}
\hline Inorganic Gases & NOX \\
\hline
\end{tabular}

Nox

$+\log ^{2}$

Remarks :

sampler signature:

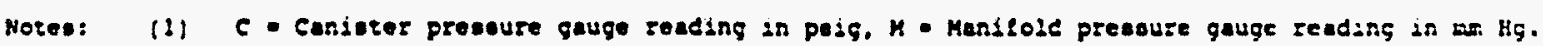

(2) P- preseure in Hg; T - semperezure in C

Figure 6. Example of a sample tag. 


\section{CALIBRATION PROCEDURES AND FREQUENCY}

This section describes calibration procedures for each analytical or measurement system used to obtain data for critical measurements, as defined in Section 1. All test and measuring equipment used in operational facilities and analytical laboratories shall be controlled in accordance with NQA-1, Element 12.

Reference standards must be traceable to nationally recognized standards. All reference standard gases must be obtained from a supplier that provides certification of the standard's specifications.

Calibration labels shall be placed on calibrated equipment to permit easy identification of calibration status by operators, QA representatives, and others. Calibration-related deficiencies, when noted, shall be entered in the deficiency log and handled in accordance with RWMC PD-RS-5.3, Nonconformance Reporting and Tracking." The RWMCSWEPP Operations manager shall ensure that deficiencies are corrected and calibrations are performed.

Instrument manuals shall be kept on file for reference purposes. Records shall be prepared and maintained for each piece of calibrated equipment to indicate that established calibration procedures have been followed. These records include the following information:

- Equipment identification/serial number

- Name of device

- Calibration and/or maintenance schedule

- Procedure(s) for calibration and/or maintenance

- Date and results of last calibration, with signature of person performing calibration

- Date for next scheduled calibration

- Facility or organization performing calibration

- Calibration procedure

- Nonconforming conditions related to the equipment.

RWMC PD-RS-5.11, "Control of Devices Needing Periodic Calibration or Testing," establishes the Quality Assurance Program used by RWMC Operations to ensure the continued integrity of information provided by devices needing periodic calibration or testing. When equipment is found to be out of tolerance, a nonconformance report (NCR) shall be issued in accordance with RWMC PD-RS-5.3. 
The sampling manifold shall be calibrated using a reference standard gas. The gas will be admitted to the system prior to temperature elevation, a sample will be taken, and analyses will be performed. The calibration for each system shall be checked at the beginning and end of each drum test period in both flow directions. If the calibration analysis indicates that adjustments must be made to the system to properly run the drum test, corrective actions will be taken and documented in accordance with the requirements of Section 14 of this QAPjP.

\subsection{Gas Flow Measurement}

Gas flow measurement devices may be calibrated individually or calibrated as sets of instruments (e.g., one flow measurement device and its associated electronics) kept together while the calibration is valid. The flow system (consisting of the flow measurement device and associated electronics) shall be precalibrated as a unit. The unit shall be calibrated at room temperature conditions, as specified, and for an atmospheric gas mix. The calibration for each system shall be checked at the beginning and end of each drum test period in both flow directions. If the calibration analysis indicates that adjustments must be made to the system to properly run the drum test, corrective actions will be taken and documented in accordance with the requirements of Section 14 of this QAPjP.

\subsection{Hydrogen, Methane, and Volatile Organic Compound Analyses}

The on-line mass spectrometer, which will be used to measure the concentrations of hydrogen, methane, organics, and mass balance parameters in the generated gas must be calibrated. Certified gas standards shall be used for calibration of the analytical instrumentation. The instrument is selfcalibrating. Calibrations are conducted at a period determined by the computer that runs the instrument. The procedures used in the calibration process are described in RWMC/SWEPP Programs DOP RO 4.3.7.

\subsection{Temperature}

Thermometers and thermocouples shall be calibrated to National Institute of Standards and Technology (NIST) traceable temperature standards prior to initial use and annually thereafter. 


\section{ANALYTICAL PROCEDURES}

\subsection{Gas Flow Measurement}

Gas flow rates shall be measured using a flow measurement device and associated electronics. The analytical procedure, as described in DOP RO 4.3.7, is based on obtaining offgas flow rates from a 55-gal drum.

\subsection{Hydrogen, Methane, and Volatile Organic Compound Analyses}

An on-line mass spectrometer is used to analyze the concentrations of organics, relative humidity, $\mathrm{O}_{2}, \mathrm{~N}_{2}, \mathrm{CO}_{2}, \mathrm{Ar}, \mathrm{H}_{2}$, and methane $\left(\mathrm{CH}_{4}\right)$ in the offgas. Data are collected on-line and stored to a hard disk for retrieval and manipulation.

\subsection{Temperature}

Procedures for temperature measurements of the drum, the test room, and the offgas system are described in DOP RO 4.3.7. Temperature measurements shall be taken daily. 


\section{DATA REDUCTION, VALIDATION, AND REPORTING}

For the purposes of data reduction, validation, and reporting requirements, the following shall be considered minimum:

Data Reduction-Data shall be reduced according to the following minimum requirements:

- All electronic data must be stored appropriately to ensure that sample and QC data are retrievable

- All analytical instruments and data acquisition and control systems must be connected to an uninterruptible power supply

- Techniques used to reduce data shall be consistent with the analytical methods used to generate the data

- Reporting units shall be consistent with the method used

- All analytical data must be reported to the significant figures requested in this QAPjP or the QAPP, and shall be appropriate for the method.

Data Validation-One hundred percent of the data shall receive a technical review. This review shall ensure the following:

- Data were reduced according to the appropriate method and the reporting units are correct

- Calculations have been verified by a valid calculation program, a spot check of verified calculations programs, or a $100 \%$ check of all hand calculations

- All variances from the specified method are documented and include the rationale for the variations

- All calculation requirements have been met

- Data are complete

- QC results are within established control limits or data have been appropriately qualified

- QC practices are documented

- QC criteria that were not met are documented.

Data Reporting-All data shall be reported on standard forms. 


\subsection{Gas Flow Measurement}

\subsubsection{Data Reduction}

The gas flow measurements shall be recorded in units of cubic centimeters per second and should be limited to two significant figures. The flow measurements recorded at the end of the test procedure should be converted to gas generation rates in units of moles per second using the following equation:

$G_{T}=\frac{P V_{F}}{R T}$

where

$$
\begin{aligned}
& \mathrm{G}_{\mathrm{T}}=\text { total gas generation rate (moles/sec) } \\
& V_{\mathrm{F}}=\text { gas flow measurement (cc/sec) } \\
& \mathrm{P}=\text { pressure in atmospheres (atm) } \\
& T=\text { temperature in Kelvin }(\mathrm{K}) \\
& \mathrm{T}=82.04 \mathrm{cc} \cdot \mathrm{atm} / \text { mole } \mathrm{K} .
\end{aligned}
$$

This rate will be compared to the corresponding limit for the shipping category of the waste container (Table 9).

\subsubsection{Date Validation}

The following items shall be verified:

- Dates, times, room temperatures, drum temperatures, and barometric pressures reported in the proper units

- Gas flow rates reported in proper units

- Total gas generation rate calculated properly.

\subsubsection{Data Reporting}

The following information shall be reported:

- Total gas generation rate in moles per second

- Temperature in Kelvin

- Ambient (room) temperature in atmospheres. 
Table 9. Maximum total gas release rates for test categories.

\begin{tabular}{|c|c|c|c|}
\hline \multicolumn{2}{|c|}{ 55-gallon drums } & \multicolumn{2}{|c|}{ Experimental bins overpacked in $\mathrm{SWB}^{\mathrm{a}}$} \\
\hline $\begin{array}{l}\text { Payload shipping } \\
\text { category }\end{array}$ & $\begin{array}{l}\text { Maximum gas release rate } \\
\text { (moles/sec/container) }^{b}\end{array}$ & $\begin{array}{l}\text { Payload shipping } \\
\text { category }\end{array}$ & $\begin{array}{l}\text { Maximum gas relcase rate } \\
{\text { (moles/sec/container })^{b}}^{\text {(mole }}\end{array}$ \\
\hline I.LAOT & $6.48 E-07$ & & \\
\hline I.1A1T & $6.48 \mathrm{E}-07$ & & \\
\hline I.1A2T & $6.48 E-07$ & I.1D2T & $3.24 E-06$ \\
\hline 1.1A3T & $6.48 E-07$ & & \\
\hline 1.2A0T & $6.48 \mathrm{E}-07$ & & \\
\hline $1.2 \mathrm{AlT}$ & $6.48 \mathrm{E}-07$ & & \\
\hline $1.2 \mathrm{~A} 2 \mathrm{~T}$ & $6.48 \mathrm{E}-07$ & $1.2 \mathrm{D} 2 \mathrm{~T}$ & $3.24 E-06$ \\
\hline $1.2 \mathrm{~A} 3 \mathrm{~T}$ & $6.48 \mathrm{E}-07$ & & \\
\hline $1.2 \mathrm{A4T}$ & $6.48 E-07$ & & \\
\hline I.3AOT & $6.48 E-07$ & & \\
\hline I.3A1T & $6.48 E-07$ & & \\
\hline $1.3 \mathrm{~A} 2 \mathrm{~T}$ & $6.48 \mathrm{E}-07$ & $1.3 \mathrm{D} 2 \mathrm{~T}$ & $3.24 E-06$ \\
\hline [.3A3T & $6.48 E-07$ & & \\
\hline $1.3 \mathrm{~A} 4 \mathrm{~T}$ & $6.48 \mathrm{E}-07$ & & \\
\hline II.1AOT & $6.36 \mathrm{E}-07$ & & \\
\hline II.1AIT & $6.36 \mathrm{E}-07$ & & \\
\hline 11.1A2aT & $6.36 \mathrm{E}-07$ & & \\
\hline II.1A2T & $6.36 \mathrm{E}-07$ & II.1D2T & $3.20 \mathrm{E}-06$ \\
\hline II.1A3T & $6.36 E-07$ & & \\
\hline II.1A4T & $6.36 E-07$ & & \\
\hline II.1AST & $6.36 \mathrm{E}-07$ & & \\
\hline II.1A6T & $6.36 \mathrm{E}-07$ & & \\
\hline III.1AOT & $6.36 \mathrm{E}-07$ & & \\
\hline III.1AIT & $6.36 \mathrm{E}-07$ & & \\
\hline III.1A2aT & $6.36 \mathrm{E}-07$ & & \\
\hline III.1A2T & $6.36 E-07$ & III.1D2T & $3.20 \mathrm{E}-06$ \\
\hline III.1A3T & $6.36 E-07$ & & \\
\hline III.1A\&T & $6.36 \mathrm{E}-07$ & & \\
\hline III.1AST & $6.36 \mathrm{E}-07$ & III.IDST & $3.20 \mathrm{E}-06$ \\
\hline III.1A6T & $6.36 E-07$ & & \\
\hline IV.1AIT & $6.51 \mathrm{E}-07$ & & \\
\hline IV.1A2T & $6.51 E-07$ & IV.1D2T & $3.26 \mathrm{E}-06$ \\
\hline a. SWB - standard & te box. & & \\
\hline
\end{tabular}


An example of the reporting format to be used for this information is provided in Figure 7.

\subsection{Hydrogen and Methane Gas Analyses}

\subsubsection{Data Reduction}

The hydrogen concentration shall be converted to a hydrogen generation rate using the following equation:

$$
G_{H}=\int_{0}^{b} G_{T} \times X_{H}
$$

where

$$
\begin{aligned}
& G_{H}=\text { hydrogen generation rate (moles/sec) } \\
& G_{T}=\text { total gas generation rate (moles/sec) } \\
& X_{H}=\text { mole fraction of hydrogen at time } t .
\end{aligned}
$$

This rate will be compared to the corresponding limit for the shipping category of the waste container (Table 9).

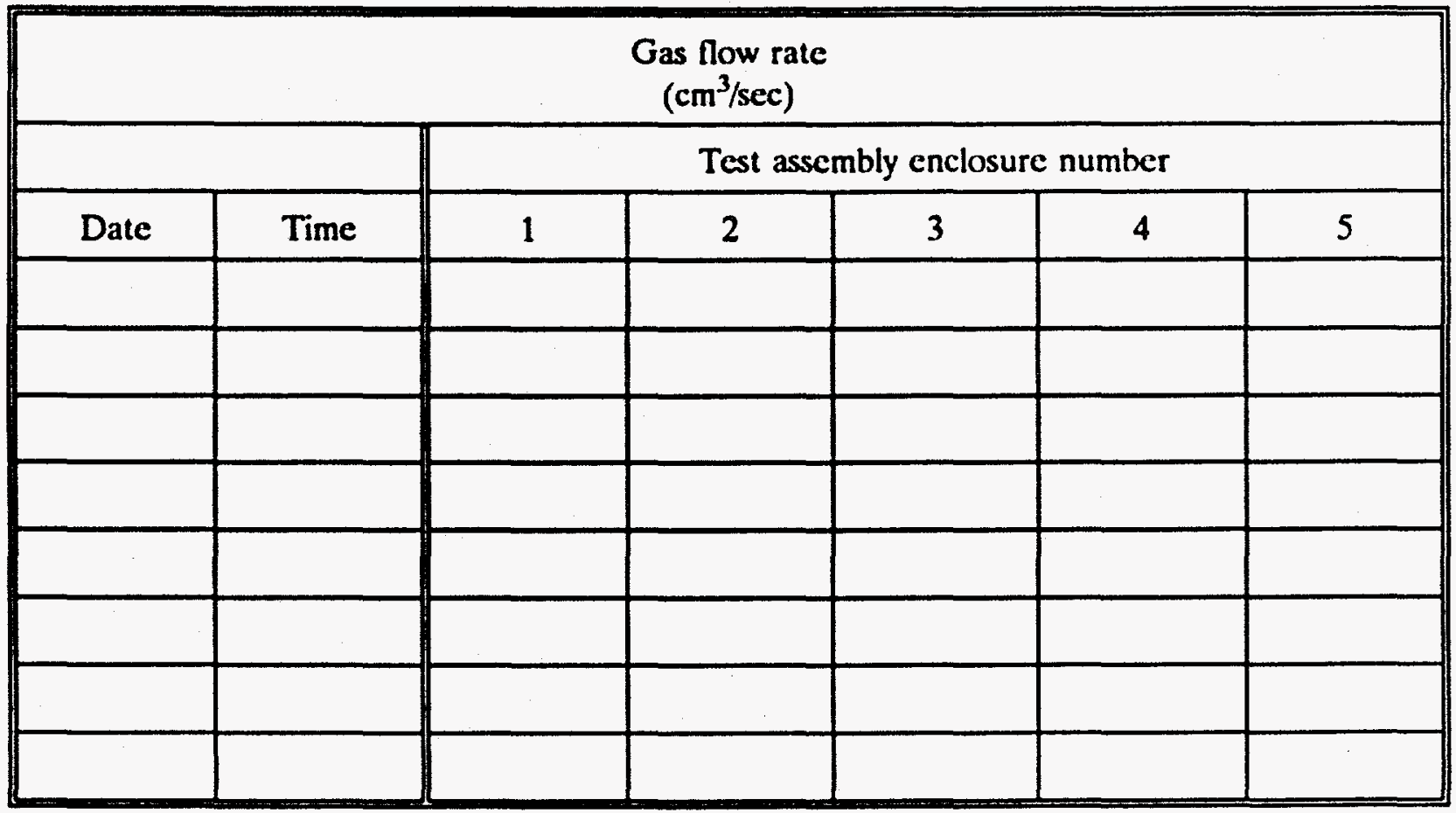

Figure 7. Example of a reporting form for gas flow measurements. 


\subsubsection{Data Validation}

Hydrogen and methane analyses shall be verified to ensure that they are reported in proper units.

\subsubsection{Data Reporting}

The hydrogen generation rate, in moles/second, will be reported for these analyses. An example of the reporting format to be used is provided in Figure 8.

\subsection{Volatile Organic Compound Analyses}

\subsubsection{Deta Reduction}

Organic analyte concentrations shall be quantified using average relative response factors for internal standard quantitation and average response factors for external standard quantitation. Target compound concentrations shall not be blank corrected. Results from blanks run in association with samples shall be reported separately, and any target compounds detected shall be nlagged.

\subsubsection{Data Validation}

In addition to general data validation measures, the reported data shall be reviewed to ensure that quality assurance objectives have been met, or nonconformances have been noted.

\begin{tabular}{||c||c|c|c|c|c|c||}
\hline \multicolumn{7}{|c|}{ Co centration of hydrogen and methane in the offgas } \\
(volume percent)
\end{tabular}

Figure 8. Example of a reporting form for hydrogen/methane analyses. 


\subsubsection{Data Reporting}

All results shall be reported in parts per million on a volume/volume basis (ppmv) and shall be limited to two significant figures. The reporting forms and requirements described in the Environmental Chemistry Laboratory Qualty Assurance Project Plan for the Waste Isolation Pilot Plant Experimental Test Progran (EG\&G Idaho 1993), appropriately modified for this Program, will meet the requirements of this QAPjP and the QAPP.

\subsection{Mass Balance Parameters}

\subsubsection{Data Reduction}

Mass balance parameters shall be converted from moles/second, in the case of hydrogen and methane, to volume percent in accordance with the following equations:

$$
\begin{aligned}
& V_{H}=\frac{G_{H}}{G_{T}}(100) \\
& V_{C H_{4}}=\frac{G_{C H_{4}}}{G_{T}}(100)
\end{aligned}
$$

where

$$
\begin{array}{ll}
V_{H} & =\text { volume percent hydrogen } \\
V_{\mathrm{CH}_{4}}= & \text { volume percent methane } \\
\mathbf{G}_{\mathbf{H}} & =\text { generation rate of hydrogen } \\
\mathbf{G}_{\mathrm{CH}_{4}} & =\text { generation rate of methane. } \\
\mathbf{G}_{\mathbf{T}} & =\text { total gas generation rate }
\end{array}
$$

\subsubsection{Data Validation}

Calculations used to convert mass balance data to volume percent shall be checked to ensure that calculations are made correctly.

\subsubsection{Data Reporting}

Relative humidity, $\mathrm{O}_{2}, \mathrm{~N}_{2}, \mathrm{CO}_{2}$, and Ar will be reported in terms of volume percent. An example of the reporting format for mass balance parameters is provided as Figure 9. 


\begin{tabular}{|c|c|c|c|c|c|c|c|}
\hline \multicolumn{8}{|c|}{$\begin{array}{l}\text { Concentration of components in the offgas used for mass balance calculations } \\
\text { (volume percent) }\end{array}$} \\
\hline \multirow[b]{2}{*}{ Date } & \multirow[b]{2}{*}{ Time } & & \multicolumn{5}{|c|}{ Test assembly enclosure number } \\
\hline & & & 1 & 2 & 3 & 4 & 5 \\
\hline & & $\mathrm{N}_{2}$ & & & & & \\
\hline & & $\mathrm{O}_{2}$ & & & & & \\
\hline & & $\mathrm{CO}_{2}$ & & & & & \\
\hline & & Ar & & & & & \\
\hline & & $\mathbf{N}_{2}$ & & & & & \\
\hline & & $\mathrm{O}_{2}$ & & & & & \\
\hline & & $\mathrm{CO}_{2}$ & & & & & \\
\hline & & Ar & & & & & \\
\hline & & $\mathrm{N}_{2}$ & & & & & \\
\hline & & $\mathrm{O}_{2}$ & & & & & \\
\hline & & $\mathrm{CO}_{2}$ & & & & & \\
\hline & & Ar & & & & & \\
\hline
\end{tabular}

Figure 9. Example of a reporting form for mass balance parameters.

\subsection{Temperature}

\subsubsection{Data Reduction}

Temperature measurements will be reduced using the following equations:

$\left(T_{F}-32\right) \frac{5}{9}=T_{C}$

$T_{c}+273.15=T_{k}$

where

$$
\begin{aligned}
& T_{F}=\text { temperature in }{ }^{\circ} \mathrm{F} \\
& T_{C}=\text { temperature in }{ }^{\circ} \mathrm{C} \\
& T_{K}=\text { temperature in } \mathrm{K}
\end{aligned}
$$




\subsubsection{Data Validation}

Temperature data shall be checked to ensure that:

- All temperatures are reported as needed for drum, room, and offgas stream temperatures.

- All temperatures are converted properly from ${ }^{\circ} \mathrm{F}$ or ${ }^{\circ} \mathrm{C}$, to $\mathrm{K}$.

\subsubsection{Data Reporting}

Temperature shall be reported in $\mathrm{K}$. An example of the reporting format is provided as Figure 10.

\begin{tabular}{|c|c|c|c|c|c|c|c||}
\hline \multicolumn{9}{|c|}{$\begin{array}{c}\text { Drum and offgas temperature, } \\
\left({ }^{\circ} \mathrm{F}\right)\end{array}$} \\
\hline \multirow{2}{*}{ Date } & Time & & \multicolumn{5}{c|}{ Test assembly enclosure number } \\
\hline & & 1 & 2 & 3 & 4 & 5 \\
\hline & & Drum & & & & & \\
\hline & & Offgas & & & & & \\
\hline & & Drum & & & & & \\
\hline & & Offgas & & & & & \\
\hline & & Drum & & & & & \\
\hline & & Offgas & & & & & \\
\hline & & Drum & & & & & \\
\hline & & Offgas & & & & & \\
\hline & & Drum & & & & & \\
\hline & & Offgas & & & & & \\
\hline & & Drum & & & & & \\
\hline & & Offgas & & & & & \\
\hline
\end{tabular}

Figure 10. Example of a reporting form for temperature measurements. 


\section{INTERNAL QUALITY CONTROL CHECKS AND FREQUENCY}

Internal QC checks are required for both field and laboratory activities. Control of these activities shall be in compliance with ASME NQA-1, Elements 9 and 11.

\subsection{Sampling}

QC checks include sampling manifold blanks and calibration reference standard samples. Once a drum has been placed in the test apparatus, and prior to initiating the test (i.e., heating the drum), the sampler will be purged and a sampling manifold blank will be taken. A standard gas (calibration reference standard) will then be introduced to the sampler, and a sample (calibration reference standard sample) will be taken to ensure that the sampler is correctly calibrated. The sampler will again be purged, and another sampling manifold blank sample will be collected to ensure that the sampler is clean and free of any remaining gases (i.e., to ensure that the sampling lines are not contaminated).

A field blank sample will be collected periodically to establish the background levels of the contaminants of interest.

\subsection{Hydrogen, Methane, and Volatile Organic Compound Analyses}

QC checks that shall be used to include calibration reference standard samples. The mass spectrometer will be calibrated using a known standard at the beginning of the tests for each drum. 


\section{PERFORMANCE AND SYSTEMS AUDITS}

Operations audits shall be conducted on a periodic basis by both internal and external organizations. The organizations and frequency of these audits are described below.

\subsection{Audit Personnel}

All auditors shall be independent of any direct responsibility for performance of the activities they audit.

A quarterly review of the Program shall be performed by the RWMC quality engineer, as identified in RWMC PD-RS-5.7, "Quality Program Monitoring and Surveillance." The project directive establishes the responsibilities and procedures for the monitoring and surveillance of RWMC quality programs.

\subsection{Scope and Frequency of Audits}

Internal audits of Program activities shall be conducted at least annually. Audits shall be performed in accordance with the written procedures or checklists. Audit results shall be documented by auditing personnel and reported by the lead auditor to the INEL Gas Generation Testing Program manager. The audit report shall be signed by the lead auditor and shall include the following information:

- Description of the audit scope

- Identification of the auditors

- Identification of persons contacted during audit activities

- A summary of audit results, including a statement on the effectiveness of the QA program elements audited

- Description of each reported adverse audit finding in sufficient detail to determine the cause and to enable corrective action by the audited organization.

When corrective actions are required, a schedule that details all follow-up activities and final resolution shall be provided by the audit team to the INEL Gas Generation Testing Program manager. It is the responsibility of the lead auditor to ensure that all audit findings are resolved and that appropriate corrective actions are implemented in a timely manner. Follow-up action shall be taken by the responsible management organization to verify that corrective action is accomplished as scheduled. Audit records shall include audit plans, audit reports, written replies, and the record of completion of corrective actions. 


\section{PREVENTIVE MAINTENANCE}

The purpose of the Preventive Maintenance Program is to identify, control, perform, and track preventive maintenance activities on systems, equipment, and components. The Program also initiates corrective action and tracking of deficiencies jdentified in the course of preventive maintenance. Preventive maintenance checklists shall be used in accordance with RWMC PD-RS-27, "Conduct of RWMCSWEPP Operating and Maintenance Program." The directive defines a system and assigns responsibilities for identification, control, and accomplishment of preventive maintenance on fixed (nonmobile) equipment and facilities at the RWMC/SWEPP in compliance with the EG\&G Idaho Facility Maintenance Management Manual. This directive establishes policy for routine operating and maintenance activities at the SWEPP.

RWMC Operations personnel shall track preventive maintenance programs and maintain vendor data files. RWMC Operations personnel shall maintain the deficiency log, evaluate deficiencies, and initiate the necessary corrective actions in accordance with RWMC PD-RS-5.3, "Nonconformance Reporting and Tracking." RWMC Operations personnel shall determine the need for and recommend the spare parts and the quantity of spare parts for RWMC-related systems and equipment.

RWMC PD-RS-1.9, "RWMC/SWEPP Preventive Maintenance Program," defines a system and responsibilities for the identification, control, and accomplishment of preventive maintenance on RWMCSWEPP fixed (nonmobile) equipment and facilities on compliance with the EG\&G Idaho Facility Maintenance Management Manual. The SWEPP O\&MM, Section 4, gives specific guidelines and checklists for accomplishing preventive maintenance on the systems, equipment, or components at the SWEPP facility. 


\section{SPECIFIC AND ROUTINE PROCEDURES TO ASSESS DATA QUALITY}

The precision and accuracy of all quantitative data generated must be routinely assessed. In accordance with ASME NQA-1, Element 11, characteristics to be tested and test methods to be employed shall be specified. The specific equations to assess precision, accuracy, completeness, and the MDL are described below.

\subsection{Precision}

Precision is a quantitative measure that characterizes the amount of variability and bias inherent in a given data set. Precision refers to the level of agreement among repeated measurements of the same characteristic. below:

For duplicate measurements, the precision expressed as the RPD is calculated as shown

$R P D=\frac{C_{1}-C_{2}}{\left(C_{1}+C_{2}\right) / 2} \cdot 100$

where

$C_{1}=$ value obtained by analyzing the larger of the duplicate samples

$C_{2}=$ value obtained by analyzing the smaller of the duplicate samples.

For three or more replicate measu, ments, the precision expressed as the RSD is calculated as shown below:

$\% R S D=\frac{s}{\bar{y}} \cdot 100$

where

$$
\begin{aligned}
& s=\text { standard deviation } \\
& y=\text { mean of the replicate sample analyses. }
\end{aligned}
$$

The standard deviation, $s$, is defined as follows:

$$
s=\sqrt{\sum_{i=1}^{n} \frac{\left(y_{i}-\bar{y}\right)^{2}}{n-1}}
$$


where

$y_{i}=$ measured value of the $i^{\text {th }}$ replicate sample analysis measurement

$\mathbf{n}=$ number of replicate analyses.

\subsection{Accuracy}

Accuracy is a quantitative measure of the degree to which the data agree with the true or known value of the parameter being measured. Accuracy is expressed as \% $\mathrm{R}$.

For situations where a standard reference material is used, the $\% \mathrm{R}$ is calculated as follows:

$\% R=\frac{C_{m}}{C_{s m}} \cdot 100$

where

$C_{m}=$ measured concentration value obtained by analyzing the sample

$\mathrm{C}_{\mathrm{smm}}=$ "true" or certified concentration of the analyte in the sample.

For measurements where matrix spikes are used, the $\% \mathrm{R}$ is calculated as follows:

$\% R=\frac{S-U}{C_{s o}} \cdot 100$

where

$$
\begin{aligned}
& \mathrm{S}=\text { measured concentration in the spiked aliquot } \\
& \mathrm{U}=\text { measured concentration in the unspiked aliquot } \\
& \mathrm{C}_{\mathbf{w}}=\text { actual concentration of the spike added. }
\end{aligned}
$$

\subsection{Completeness}

Completeness refers to the amount of data that are successfully collected with respect to the amount intended in the experimental design. A certain percentage of the intended amount of data must be successfully collected for conclusions based on the data to be valid. Completeness is an issue because missing data may reduce the precision of measurements, introduce bias, and, therefore, lower the level of confidence in the conclusions. Laboratory completeness, expressed as the percent complete $(\% \mathrm{C})$, may be calculated as follows: 
$\% C=\frac{V}{n} \cdot 100$

where

$\mathbf{V}=$ number of valid analytical results obtained

$\mathrm{n}=$ total number of determinations required for the actual number of samples collected.

\subsection{Method Detection Limit}

The MDL is the minimum concentration of an analyte that can be measured and reported with $99 \%$ confidence that the analyte concentration is greater than zero. The MDL for all measurements is defined as follows:

$M D L=t_{(n-1,1-2-.99)} \bullet s$

where

$T_{(n-1,1-e-.99)}=t$ distribution value appropriate to a $99 \%$ confidence level and a standard deviation estimate with $\eta-1$ degrees of freedom

$s$

$=\quad$ standard deviation of replicate measurements. 


\section{CORRECTIVE ACTION}

Conditions adverse to the QA requirements specified in this document shall be promptly identified and corrected as soon as practical. The root cause of any adverse condition that affects compliance with the quality requirements shall be determined and action shall be taken to preclude its recurrence.

\subsection{Nonconformance}

Nonconformances are uncontrolled and unapproved deviations from an approved plan, procedure, or expected result. Nonconforming items and activities are those that do not meet the Program requirements, procurement document criteria, or approved work procedures.

Nonconforming items shall be identified and segregated, and the affected organization(s) shall be notified, in accordance with ASME NQA-1, Elements 15 and 16, to prevent their inadvertent use or installation. Responsibilities and procedures for deficiency/nonconformance reporting and tracking are in RWMC PD-RS-5.3. Specific evaluation, correction, and closeout procedures are addressed in the EG\&G Idaho Company Procedures Manual, Section 9.7, "Deficiency Log and Nonconformance Reporting and Tracking."

An NCR (Figure 11) shall be initiated when controlled items do not satisfy specified acceptance criteria. Once a nonconformance has been identified, the NCR must be transmitted to the INEL Gas Generation Testing Program manager within two working days. Each nonconformance report shall describe the following items:

- Identification of the individual(s) identifying or originating the nonconformance

- Description of the nonconformance

- Method(s) for correcting the nonconformance (corrective action) or description of the variance granted

- Schedule for completing the corrective action

- Cause of nonconformance (if known) and action to prevent reoccurrence

- Any required approval signatures.

\subsection{Varlances}

Variances are approved and controlled changes to approved plans or procedures caused by unusual or nonroutine occurrences that affect operations, but not the ability to achicve the performance standards or quality requirements specified. When a variance is required, the person identifying the need for the variation must notify the INEL Gas Generation Testing Program manager and the RWMC quality engineer. A record of variance (Figure 12) shall be prepared and transmitted to the INEL Gas Generation Testing Program manager. This form must be completed prior to the initiation of the activity to document the variation from normal, approved 


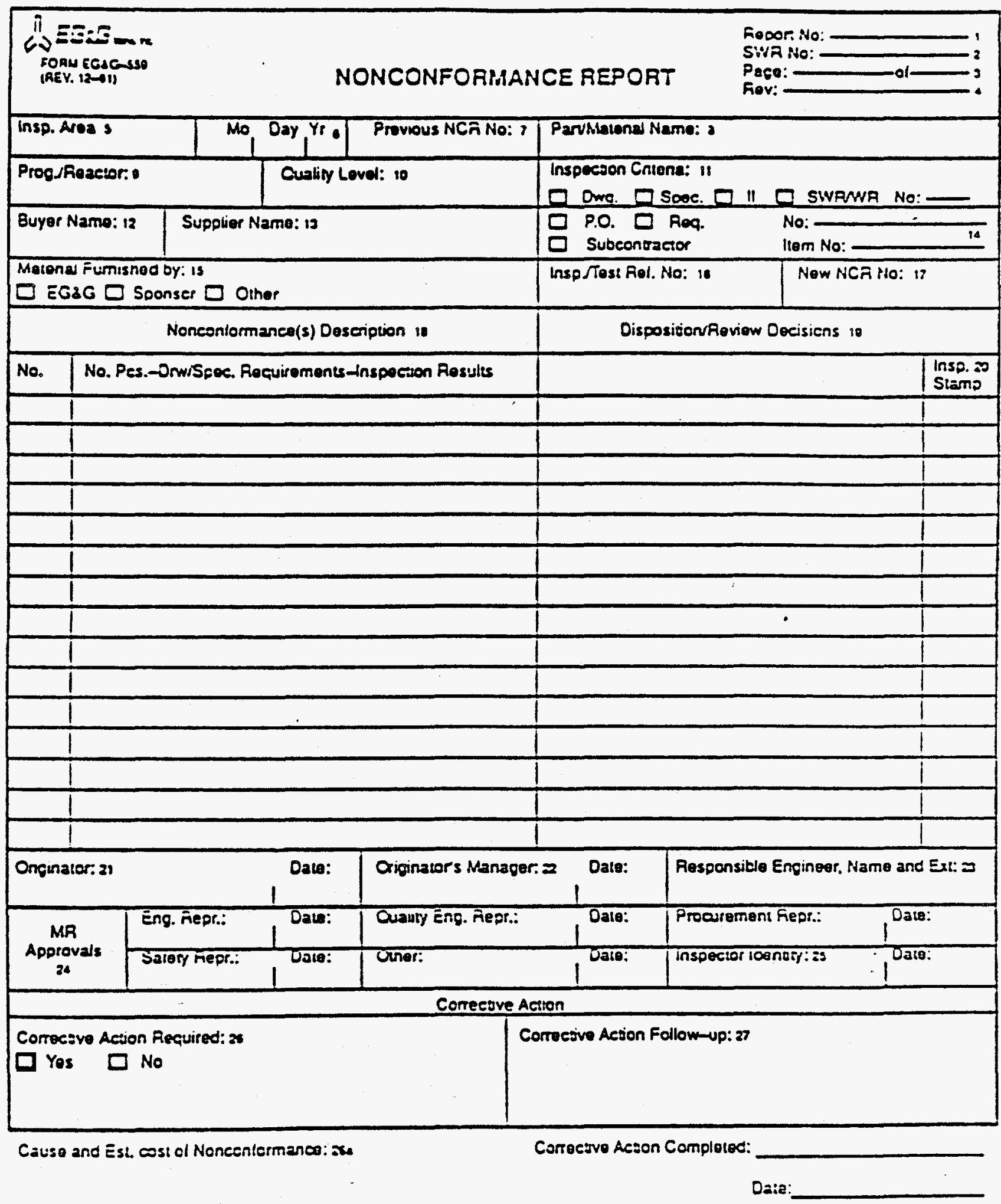

Figure 11. Example of a nonconformance report. 
SUBJECT ACTIVITY:

ITEM(S) AFFECTED:

ITEM I.D.\$:

PROCEDURE NO.:

STEP NO.:

DESCRIPTION OF VARIANCE:

REASON FOR VARIANCE:

SPECIAL EQUIPMENT OR PERSONNEL REQUIRED:

INITIATOR:

DATE:

APPROVALS

\section{REVIENS}

\section{Site Project Manager/Oate}

Figure 12. Example of a variance form. 
procedures. Program personnel shall assess the significance of the variance and determine whether further notifications are required.

The ECL shall implement procedures to control variances to approved procedures. When a variance is required, the person identifying the need for the variance must notify the INEL Gas Generation Testing Program manager using the variance form provided as Figure 12, or equivalent. 


\section{QUALITY ASSURANCE REPORTS TO MANAGEMENT}

Conditions adverse to quality shall be identified, documented, and reported to management, and follow-up action shall be tracked to final closure.

The status of Program activities shall be routinely reported to management. These reports shall include, as applicable, the following items:

- Changes recommended to this QAPjP

- Significant quality problems, recommended solutions, and corrective actions taken

- Discussion of open NCRs

- Results of audits and surveillances within the scope of this QAPjP. 


\section{REFERENCES}

American Society of Mechanical Engineers (ASME), 1989, "Quality Assurance Program Requirements for Nuclear Facilities," NQA-1, American Socicty of Mechanical Engineers, New York, New York.

EG\&G Idaho Company Procedures Manual, current issue.

EG\&G Idaho, Inc., 1993, Environmental Chemisty Laboratory Quality Assurance Plan for the Waste Isolation Pilot Plant Experimental Test Program, EGG-WM-9570, Rev. 1, April 2, 1993.

NuPac, 1992, Safety Analysis Report for the TRUPACT-II Shipping Package, Rev. 12, Nuclear Packaging, Inc., Federal Way, Washington.

U.S. Department of Energy (DOE), 1991a, DOE Order 5700.6C, "Quality Assurance," U.S. Department of Energy, Washington, D.C.

U.S. Department of Energy (DOE), 1991b, Quality Assurance Program Plan for the Waste Isolation Pilot Plant Experimental Waste Characterization Program, DOE/EM/48063-1, Rev. 1, U.S. Department of Energy, Washington, D.C.

U.S. Department of Energy (DOE), 1991c, WIPP Waste Characterization Program Sampling and Analysis Guidance Manual, DOE/WIPP91-043, Rev. 0, U.S. Department of Energy, Washington, D.C.

U.S. Department of Energy (DOE), 1992a, TRUPACT-II Content Codes (TRUCON), DOE/WIPP 89-004, Rev. 6, U.S. Department of Energy, Carlsbad, New Mexico.

U.S. Department of Energy (DOE), 1992b, Quality Assurance Program Plan for the Waste Isolation Pilot Plant Experimental-Waste Characterization Program, DOE/EM/48063-1, Rev. 2, U.S. Department of Energy, Washington, D.C.

U.S. Department of Energy (DOE), 1993, Quality Assurance Program Plan for the TRUPACT-II Gas Generation Test Program, U.S. Department of Energy, Washington, D.C.

U.S. Environmental Protection Agency (EPA), 1983a, Guidelines and Specifications for Preparing Quality Assurance Program Plans, QAMS-004/80, EPA-600/8-83-024, U.S. Environmental Protection Agency, Washington, D.C.

U.S. Environmental Protection Agency (EPA), 1983b, Interim Guidelines and Specifications for Preparing Quality Assurance Project Plans, QAMS-005/80, EPA-600/4-83-004, U.S. Environmental Protection Agency, Washington, D.C.

U.S. Environmental Protection Agency (EPA), 1986a, National Enforcement Investigations Center Policies and Procedures, EPA-330/9-78-001-R, U.S. Environmental Protection Agency, National Enforcement Investigations Center, Denver, Colorado. 
U.S. Environmental Protection Agency (EPA), 1986b, Test Methods for Evaluating Solid Waste, Physical/Chemical Methods, SW-846, third edition, U.S. Environmental Protection Agency, Office of Solid Waste and Emergency Response, Washington, D.C.

U.S. Environmental Protection Agency (EPA), 1988, Compendium of Methods for the Determination of Toxic Organic Compounds in Ambient Air, U.S. Environmental Protection Agency, Washington, D.C. 